\title{
Synthesis of Diaryl Hydroxyl Dicarboxylic Acids from Amino Acids
}

\author{
Eronen, Aleksi E. K.
}

2020-05-01

Eronen , A E K , Mannistö , J K , Moslova , K , Nieger , M , Heliövaara , E \& Repo , T 2020 , ' Synthesis of Diaryl Hydroxyl Dicarboxylic Acids from Amino Acids ', Journal of Organic Chemistry , vol. 85 , no. 9 , pp. 5799-5806 . https://doi.org/10.1021/acs.joc.9b03320

http://hdl.handle.net/10138/327390

https://doi.org/10.1021/acs.joc.9b03320

acceptedVersion

Downloaded from Helda, University of Helsinki institutional repository.

This is an electronic reprint of the original article.

This reprint may differ from the original in pagination and typographic detail.

Please cite the original version. 


\title{
Synthesis of Diaryl Hydroxyl Dicarboxylic Acids from Amino Acids
}

\author{
Aleksi E.K. Eronen, Jere K. Mannisto, Karina Moslova, Martin Nieger, Eeva Heliövaara, and Timo Repo* \\ Department of Chemistry, University of Helsinki, A.I. Virtasenaukio 1, 00014, Helsinki, Finland \\ E-mail: timo.repo@helsinki.fi
}

\begin{abstract}
:
Herein we report a unique method for preparing diaryl hydroxyl dicarboxylic acids in a diastereospecific manner. The three-component reaction occurs between amino acid, aromatic aldehyde, and primary alcohol in alkaline solutions under microwave-assisted conditions. The dicarboxylic acids are isolated as sodium salts in high yields (up to $77 \%$ ) by direct precipitation from the reaction solution. The experimental results suggest that the diastereospecificity originates from a [3,3]-sigmatropic rearrangement followed by a sodium-assisted hydride transfer. As further shown, the previously unreported dicarboxylic acids are easily turned into corresponding $\delta$ lactones.
\end{abstract}

\section{Introduction}

The development of biomass-based economy is creating an abundant amount of protein waste which can be processed into amino acids. ${ }^{1,2}$ In advanced biorefinery concepts, amino acids are further transformed into nitrogen-containing platform chemicals, such as caprolactam. ${ }^{2-4}$ Amino acids have been extensively studied during the last 200 years, yet continue to be a source of new reactivity. Regardless of their well-established chemistry, to better utilize the available amino acids as synthetic precursors for value-added chemicals, new types of reactions are sought-after. ${ }^{4,5}$ In this respect, we report here a straightforward method for preparing previously unreported aryl-substituted hydroxy dicarboxylic acids (from hereon diacids) from various amino acids. These diacids are formed with up to four stereogenic centers in a diastereospecific manner. These diacids can be turned into the corresponding $\delta$-lactones by a simple treatment with Brønsted acid. While diacids are valuable monomers as such in polymer synthesis, $\delta$-lactones have uses as antibiotics, ${ }^{6-8}$ anticancer drugs, ${ }^{9-11}$ and food flavorings. ${ }^{12}$

We initiated our studies by focusing on the classical condensation reaction between L-phenylalanine and benzalde-hyde. Unexpectedly, in alkaline ethanol solutions under microwave-assisted conditions the reaction yielded a new, white crystalline product. Based on ${ }^{1} \mathrm{H}$ NMR, ${ }^{13} \mathrm{C}$ NMR, FT-IR spectroscopy, HRMS analysis, and Xray crystallography, the substance is the unprecedented sodium salt of 2-hydroxy-3,4-diphenylhexanedioic acid 1 (Figure 1). The ${ }^{1} \mathrm{H}$ NMR spectrum of 1 exhibits a signal in the aromatic region $(\delta 7.2-6.9 \mathrm{ppm}, \mathrm{m}, 10 \mathrm{H}, \mathrm{ArH})$ corresponding to two phenyls, while the signal at $4.61 \mathrm{ppm}(\mathrm{d}, \mathrm{J}=2.8 \mathrm{~Hz}, 1 \mathrm{H})$ is characteristic for a proton attached to a carbon bearing both hydroxyl and carboxylate groups. Further on, the protons attached to the same carbons as the phenyl groups have a large coupling constant to each other $(11.4 \mathrm{~Hz})$ suggesting that these protons have a trans-geometry and all aliphatic protons are part of the same spin system (see the Experimental Section for details). The ${ }^{13} \mathrm{C}$ NMR spectrum of 1 shows 14 nonequivalent carbons; shifts of 182 and 180 ppms are fingerprints of two different carboxylate groups while a signal at $72 \mathrm{ppm}$ arises from the $\alpha$-carbon containing both carboxylate and alcohol groups (Figure 1). Based on X-ray crystallography, the stereocenters in $\mathbf{1}$ are RRR or its enantiomer SSS due to the centrosymmetry in the crystal structure. ${ }^{13}$ As there is no amino functionality in 
the structure of $\mathbf{1}$, the result was intriguing and counterintuitive. Therefore, we took an initiative to carry out further studies and reveal mechanistic details of diacid synthesis.

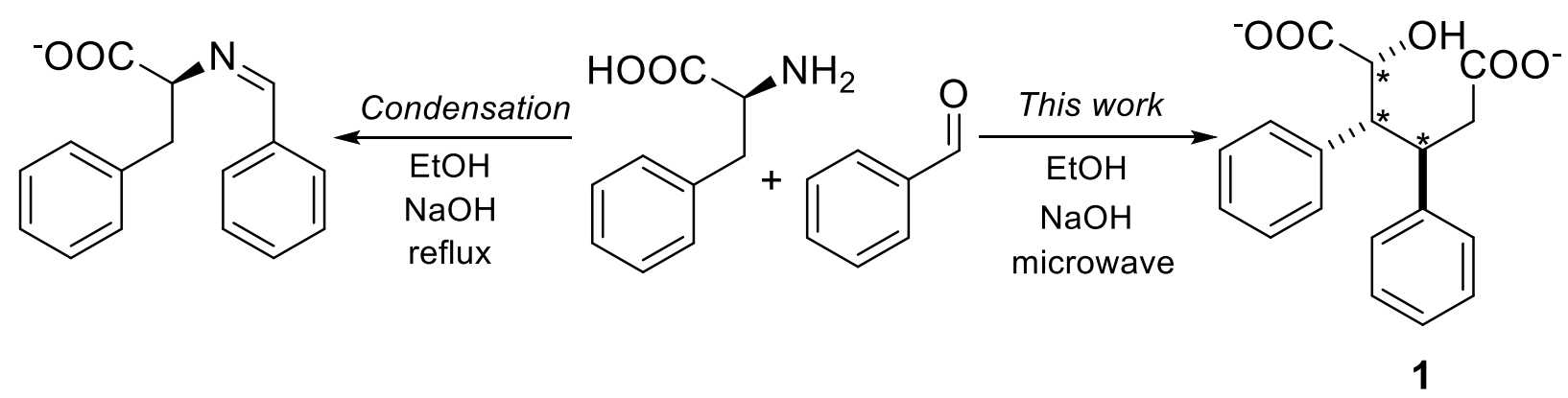

Figure 1. On the left, a classical imine condensation product between L-phenylalanine and benzaldehyde (phenylalanine, $\mathrm{N}$ (phenylmethylene)). On the right, diacid salt $\mathbf{1}$ (this work), which forms as a diastereomeric pair of RRR and SSS.

\section{Results and discussion}

The optimized isolated yield of 1 was achieved from ethanol solutions of 2 equiv of benzaldehyde and 1.5 equiv of $\mathrm{NaOH}$ at $135{ }^{\circ} \mathrm{C}$ and in 90 min using a microwave synthesizer (see Supporting Information S3, Table S1, entry 1, Method 1). Notably, when $\mathrm{CsOH}, \mathrm{KOH}$, and $\mathrm{LiOH}$ were used instead of $\mathrm{NaOH}$, the yields dropped to $2 \%, 4 \%$, and $5 \%$, respectively. Interestingly, when ethanol/tert-butanol solvent mixture was used as the reaction medium with 5 equiv of $\mathrm{NaOH}$ and benzaldehyde, isolated yield of 1 was improved drastically to 77\% (Table 1, entry 1).

The substrate scope of amino acids was extended toward L-tryptophan and L-tyrosine (Table 1, entries 2 and 3), which both bear a $\pi$-activated methylene group and undergo a similar reaction as L-phenylalanine. As the aromatic groups were now distinguishable, it became evident that the second phenyl ring $\left(R^{2}\right)$ originated from the benzaldehyde moiety. This phenomenon was confirmed by performing experiments with substituted benzylic aldehydes: $p$-tolualdehyde, $p$-anisaldehyde, 4-chlorobenzylaldehyde, and 4-fluorobenzaldehyde (see Table 1, entries 4-7). The reaction also tolerates various sterical patterns on the benzylic aldehyde shown with ortho- and meta-substituted tolualdehyde (Table 1, entries 4, 8, and 9). It is noteworthy that the structures of these novel diacids are straightforwardly modifiable with different amino acids and aromatic aldehydes. 
Table 1. Formation of diacid salts from amino acids and aromatic aldehydes in alkaline alcohol solutions.

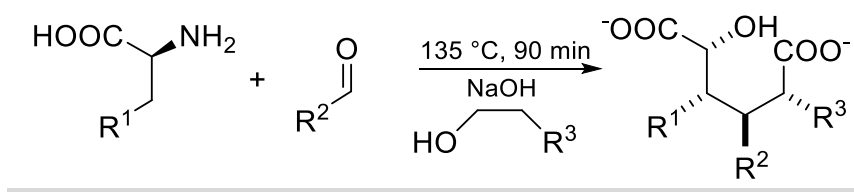

$\begin{gathered}\text { Entry/ } \\ \text { product } \\ \text { number }\end{gathered}$
12
11

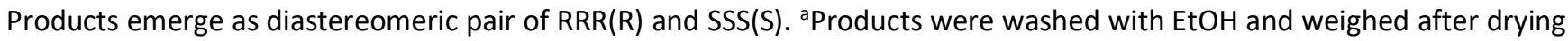
at air. Reaction conditions: amino acid $(2.0 \mathrm{mmol}), \mathrm{NaOH}\left(10 \mathrm{mmol}, 10 \mathrm{M}\right.$ at $\mathrm{H}_{2} \mathrm{O}$ solution), aromatic aldehyde (10 mmol), $75 \% / 25 \% \mathrm{v} / \mathrm{v} \%$ tert-butanol/corresponding alcohol solution $(4 \mathrm{ml})$, microwave vial was heated to $135{ }^{\circ} \mathrm{C}$ in $5 \mathrm{~min}$ and kept at $135^{\circ} \mathrm{C}$ for $90 \mathrm{~min}$.

The alcohol functionality and the missing amino functionality in $\mathbf{1}$ are noteworthy, and are fingerprints of the reaction mechanism (Figure $2 \mathrm{~A}$ ). It is likely that the reaction starts, indeed, with the classical base-catalyzed imine condensation followed by a base-assisted imine isomerization and further hydrolysis to phenylpyruvic acid I and benzyl amine II (Figure 2B). Similar transaminase steps have been reported. ${ }^{14-16}$ As the ketone group in phenylpyruvic acid $\mathbf{I}$ is in similar position as the hydroxyl group in the final product $\mathbf{1}$, we rationalized that I could be a transient intermediate of the reaction. Next, we followed the reaction by ${ }^{1} \mathrm{H}$ NMR spectroscopy and GC- MS analysis and observed benzylidenebenzylamine III as a major compound. This supports the generation of phenylpyruvic acid I and benzyl amine II under the reaction conditions. Analogously, when a substituted benzaldehyde is used, the corresponding substitution is found in the structure of III (see Supporting Information S9.4 for details). 
A)

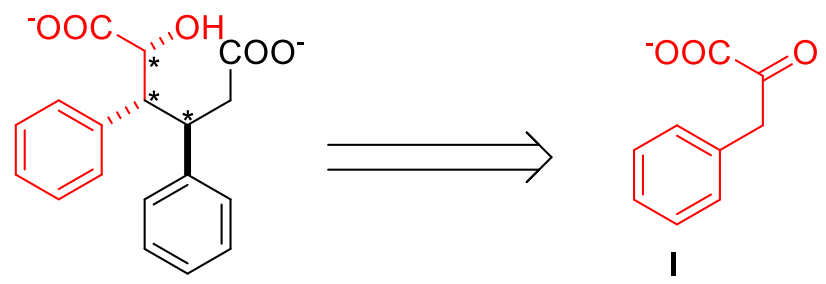

1

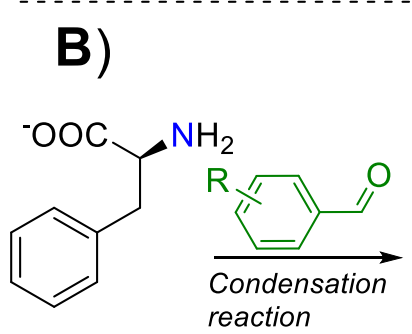

$\int_{0}$

Isomerisation<smiles>[R]c1ccc(C/N=C(/Cc2ccccc2)C(=O)[O-])cc1</smiles><smiles>[R][R]1ccc(CN=Cc2ccc(C=O)cc2)cc1</smiles>

Figure 2. A) Retrosynthetic analysis of diacid salt 1. B) The proposed reaction mechanism for the formation of phenylpyruvic acid I. Amino acid undergoes condensation reaction with benzaldehyde followed by isomerisation and hydrolysis to $\mathrm{I}$.

Intriguingly, alcohol as a solvent is also an important component in the diacid synthesis. The change from ethanol to 1-propanol brings a methyl substitution to the structure of 1 (Table 1, entry 10), underlining that the side chain $\mathrm{R}^{3}$ is easily controlled by the choice of primary alcohol. Accordingly, an ethyl substituent was observed at $\mathrm{R}^{3}$ position in NMR analysis when using 1-butanol as the primary alcohol. Similarly, 2-phenylethanol gave a phenyl substituent (Table 1, entries 11 and 12). Methanol and 2-propanol gave no products, suggesting that a chain of at least two carbons is needed and the alcohol has to be primary.

As the alcoholic solvent clearly transfers to the structure of the formed diacids, we performed a series of control experiments under microwave-assisted conditions (Figure 3A). The reaction between ethanol and benzaldehyde generated a small amount of cinnamyl alcohol (134 m/z Supporting Information S9.4). Next, we reacted benzaldehyde with 1-propanol - a longer chain alcohol - which yielded a mixture of aldehyde and alcohol analogues. In addition, the reaction between benzaldehyde and 1-octanol generated only 2(phenylmethylene)octanal. The relation between alcohol structure and the stability of an aldehyde in the applied conditions is clear; more aldehyde is observed when a longer chain alcohol is used (Figure 3B and Supporting Information S9).

The above-described reactivity is rationalized by benzaldehyde undergoing a Meerwein-Pondorf-Verley (MPV) reaction with primary alcohol generating aliphatic aldehyde and benzyl alcohol. Then the aliphatic aldehyde 
transfer occurs through keto-enol tautomerization to enolate followed by aldol condensation with another benzaldehyde molecule to form corresponding cinnamaldehyde derivatives (Figure 3B). This reactivity is similar to the known formation of cinnamaldehyde IV from ethanol and benzaldehyde. ${ }^{17,18}$ The observed alcohol analogues of cinnamaldehydes are most likely generated by MPV or Cannizzaro reactions. This motivated us to further study the role of cinnamaldehyde in the reaction.

A)

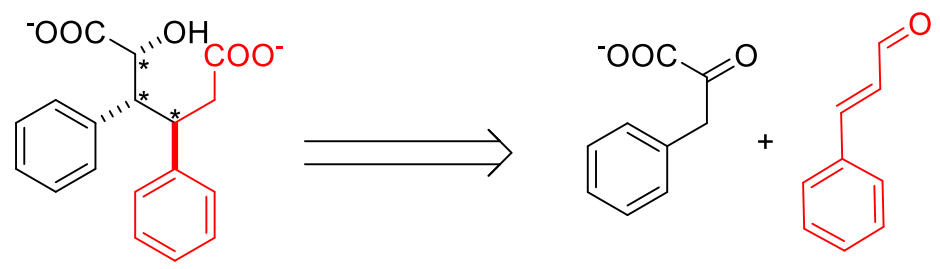

1

I

IV

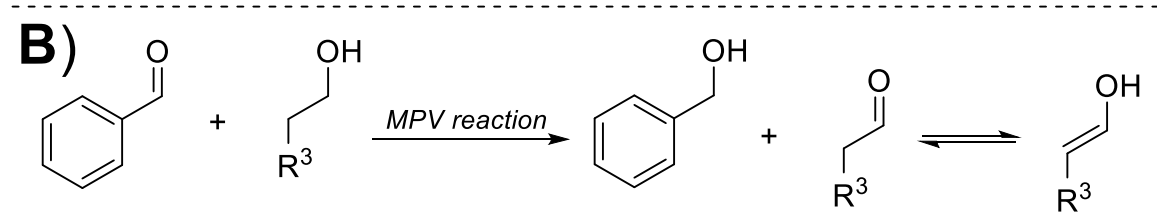

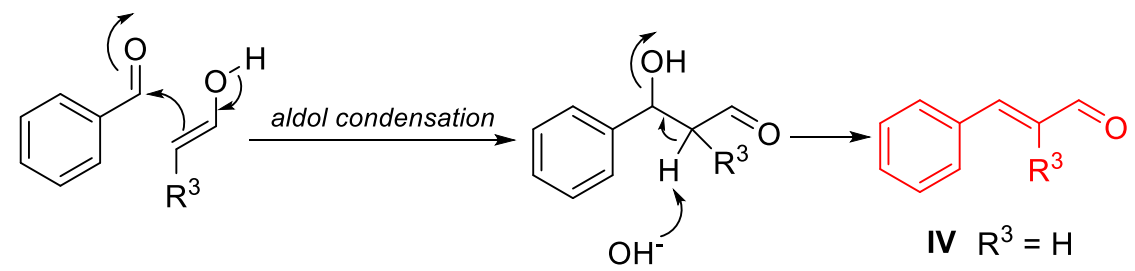

Figure 3. A) Retrosynthetic analysis of diacid salt 1. B) The proposed mechanism for the formation of IV. Meerwein-PonndorfVerley (MPV) reaction between benzaldehyde and ethanol yields benzyl alcohol and acetaldehyde followed by aldol condensation to from cinnamaldehyde IV.

To test our hypothesis that phenylpyruvic acid I and cinnamaldehyde IV have roles as building blocks of $\mathbf{1}$, we treated pure phenylpyruvic acid I and cinnamaldehyde IV under the applied reaction conditions. By this approach, product 1 was formed in good yields (56\%, see Supporting Information S9.3). The reaction is likely to proceed via the hemiacetal adduct $\mathbf{i}$, which undergoes an oxy-Cope type [3,3]-sigmatropic rearrangement reaction. The intermediate undergoes $\mathrm{H}^{+}$transfer generating $\mathrm{ii}$, which bears aldehyde and pyruvic functionalities (Figure 4). Under the applied alkaline conditions, the aldehyde undergoes nucleophilic attack by $\mathrm{OH}^{-}$. The final product 1 is formed after the parallel carbonyl units undergo $\mathrm{Na}^{+}$-ion-assisted hydride transfer from the $\varepsilon$-carbon to $\alpha$-carbon. The $\mathrm{Na}^{+}$-ion is optimal for forming an intermediate with a chair like conformation, allowing the hydride transfer reaction to take place. The ion radius of $\mathrm{Na}^{+}(1.16 \AA)$ and the $\mathrm{C}-\mathrm{H}$ bond distance $(1.09 \AA)$ are similar in length. In contrast, $\mathrm{Cs}^{+}(1.81 \AA \AA), \mathrm{K}^{+}(1.52 \AA)$, and $\mathrm{Li}^{+}(0.90 \AA)$ deviate from the $\mathrm{C}-\mathrm{H}$ bond length. ${ }^{19}$ Similar hydride transfer step has been recently reported by Xiao et al. ${ }^{20}$ 


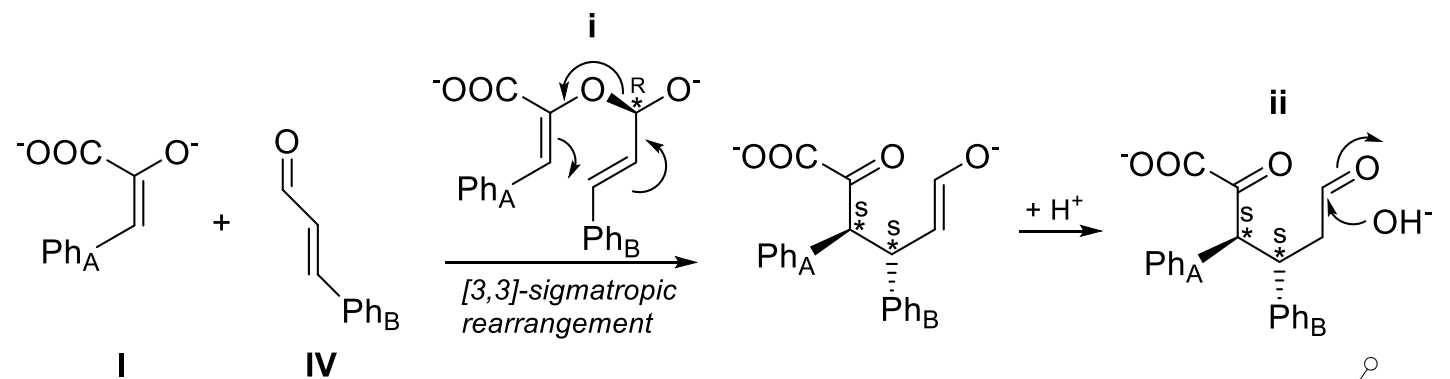

I IV

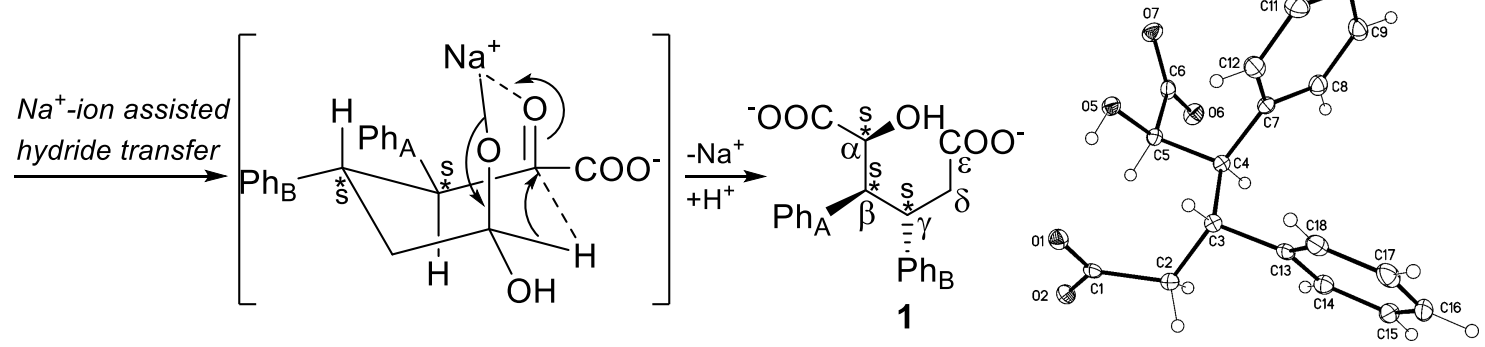

Figure 4. The proposed mechanism for the formation of 1 . The reaction produces enantiomers SSS (depicted) and RRR as observed in the crystal structure of $\mathbf{1}$. (displacement parameters are drawn at $50 \%$ probability level). ${ }^{13} \mathrm{Abbreviations} \mathrm{Ph}_{\mathrm{A}}$ indicates phenyl group originated from amino acid and $\mathrm{Ph}_{\mathrm{B}}$ phenyl group originated from benzaldehyde.

As i and ii are nondetectable intermediates, extensive ${ }^{1} \mathrm{H}$ NMR labeling studies were carried out to further ensure the reaction pathway. When $\mathrm{NaOD} / \mathrm{D}_{2} \mathrm{O}$ is used in the synthesis, the integrals of protons attached to $\beta$ - and $\delta$ carbons are clearly reduced due to the keto-enol tautomerization (Figure 5a, see Supporting Information S9.2). It is worth noting that the proton attached to the $\alpha$-carbon was not deuterated, which strongly supports an $\mathrm{H}$ transfer reaction with a nondeuterated source, namely cinnamaldehyde originated from ethanol (Figure 3B). Further studies with deuterated ethanol- $d_{6}$ confirmed the hydride transfer from ethanol- $d_{6}$. The proton attached to $\alpha$-carbon disappeared from the ${ }^{1} \mathrm{H}$ NMR spectrum (Figure 5b, see Supporting Information S9.2).

a Syntheis of 1 from

$\mathrm{D}_{2} \mathrm{O} / \mathrm{NaOD} /$ Ethanol

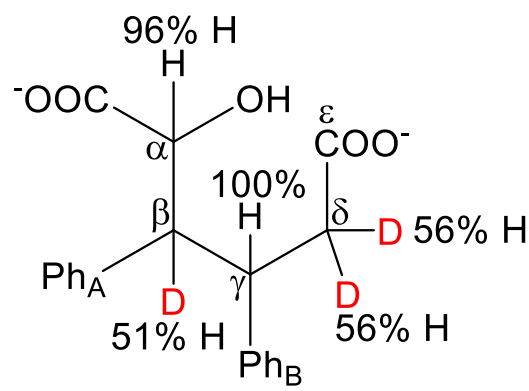

b Synthesis of 1 from

$\mathrm{H}_{2} \mathrm{O} / \mathrm{NaOH} /$ Ethanol- $\mathrm{d}_{6}$

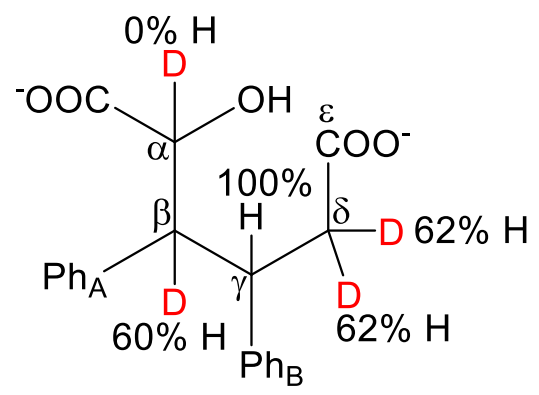

Figure 5. $H$ to $D$ ratio of 1 when the reaction was performed $(a)$ in $D_{2} \mathrm{O} / \mathrm{NaOD} /$ Ethanol solution. The ratio of $H$ to $D$ was approximately $50 \%$. (b) In $\mathrm{H}_{2} \mathrm{O} / \mathrm{NaOH} / \mathrm{Ethanol}-\mathrm{d}_{6}$ solution. The ratio of $\mathrm{H}$ to $\mathrm{D}$ was approximately $60 \%$. The proton attached to the $\alpha$-carbon is fully deuterated. 
The diastereospecifity of this multicomponent reaction arises from a [3,3]-sigmatropic rearrangement, in which a new $\mathrm{C}-\mathrm{C}$ bond is formed between the $\beta$ - and $\gamma$-carbons and two stereocenters are generated (Figure 4, intermediate i). The steric repulsion between the phenyl groups in phenylpyruvic acid I and cinnamaldehyde IV is important for the formation of these stereocenters; the reaction proceeds only if the phenyl groups are not overlapping in the hemiacetal adduct $\mathbf{i}$. The chiral hemiacetal $\mathbf{i}$ is formed either by re or si face attack of enolate form of I (E or Z) to the prochiral cinnamaldehyde IV. Hemiacetal $\mathbf{i}$ with $\mathrm{R}$ configuration gives ii as an SS diastereomer with E enolate or RR diastereomer with Z enolate. Similarly, hemiacetal i with S configuration gives ii as an RR diastereomer with $\mathrm{E}$ enolate or SS diastereomer with $\mathbf{Z}$ enolate. A detailed description is provided in the Suporting Information section 9.1.

The stereospecific formation of 1 continues by a $\mathrm{Na}^{+}$-ion-assisted hydride transfer. It requires a preorganized structure, wherein the carbonyl units are parallel. As shown in Figure 4, the hydride transfer is likely to occur via the energetically most favored chair conformation, placing aromatic substituents in the plane of the molecule. This conformation directs the hydride transfer and, as shown in the X-ray structure of $\mathbf{1}$ (see Supporting Information S10.1), leads to the third stereogenic center. For example, the intermediate ii with the RR stereocenters yields the RRR diastereomer, and the SS stereocenters yield the SSS diastereomer of 1 (see Supporting Information S9.1). When 1 is synthesized from racemic DL-phenylalanine, it yields the same racemic product as with L-phenylalanine. Clearly, stereospecificity originates from the intermediates instead of the starting materials.

The role of tert-butanol merits some further discussion. Since the typical impurity observed was unreacted amino acid, we rationalized that the formation of phenylpyruvic acid I is the reaction-limiting step. Even the addition of an excess of benzaldehyde did not enhance the yield of 1. Interestingly, when tert-butanol was used as an isomerization catalyst between amino acid and benzaldehyde, the yields were improved markedly (see Figure 2B). tert-Butanol is an inert solvent towards the MPV reaction (see Figure 3B) and therefore is unable to form cinnamaldehyde derivatives. This allowed us to control the cinnamaldehyde formation by simply altering the ethanol to tert-butanol ratio in the reaction. The improved control over the cinnamaldehyde formation frees benzaldehyde to react with the amino acid. As a result, an increased amount of phenylpyruvic acid I becomes available in the reaction solution. Alternatively, tert-butanol can generate tert-butoxide in the presence of $\mathrm{OH}^{-}$ and serve as a powerful base for extracting the proton from the $\alpha$-position. With this additional reactivity, we successfully converted a nonaromatic amino acid, L-leucine, to the corresponding diacid (Table 1, entry 13).

As shown with diacids 1, 2, 4, and 10, the products are transfered straightforwardly to lactones by refluxing in toluene with a stoichiometric amount of p-toluenesulfonic acid ( $\mathrm{TsOH}$ ) (Table 2). Importantly, this is a new pathway to prepare aryl-substituted $\delta$-lactone acids which are often tedious to synthesize and, therefore, rare. $^{21-23}$ 
Table 2. Formation of $\delta$-lactone acids from various hydroxyl diacids

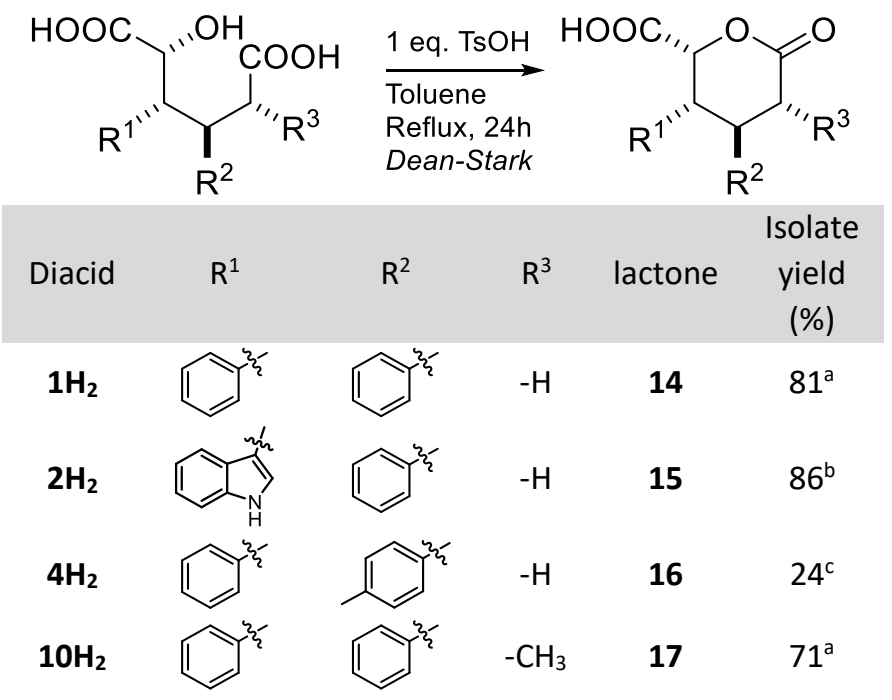

${ }^{a}$ Reaction conditions: Diacid $(2.0 \mathrm{mmol})$, TsOH $(2.0 \mathrm{mmol})$, toluene $(30 \mathrm{ml}), 24 \mathrm{~h}$, reflux (Dean-Stark apparatus). ${ }^{\mathrm{b}}$ Diacid $(1.0$ $\mathrm{mmol})$ and $\mathrm{HCl}(1 \mathrm{mmol})$ instead of $\mathrm{TsOH}$. ${ }^{\mathrm{C}} \mathrm{As}$ in a, but $\mathrm{TsOH}(4.0 \mathrm{mmol}), 48 \mathrm{~h}$.

\section{Conclusions}

To summarize, we have successfully synthesized unprecedented, aryl-substituted dicarboxylic acids (1-13) by multicomponent, one-pot reaction from amino acids $\left(R^{1}\right)$, substituted benzaldehydes $\left(R^{2}\right)$, and primary alcohols $\left(R^{3}\right)$ in alkaline solutions. The products are composed of in situ generated pyruvic acid $\mathbf{I}$ and cinnamaldehyde IV, which react together via a [3,3]-sigmatropic oxy-Cope rearrangement, followed by $\mathrm{Na}^{+}$-ion-assisted hydride transfer. The diacids form with up to four stereogenic centers in a diastereospecific manner. Overall, this is a new and straightforward synthetic method for diaryl hydroxyl dicarboxylic acids, which enables their systematic modification. As further shown, the diacids are straightforwardly turned into novel aryl-substituted $\delta$-lactone acids in the presence of a Brønsted acid.

\section{Experimental section}

General Information. All chemicals were obtained from commercial sources. Amino acids, phenylpyruvic acid, cinnamaldehyde, 1-propanol, 1-butanol, tert-butanol, and substituted aromatic aldehydes were all purchased from Sigma-Aldrich and used without further purification. Ethanol was purchased from VWR chemicals (96\%). Water used in the experiments was obtained from Milli-Q water purification system. Benzaldehyde was purchased from Acros organics and used as such. Labeled ethanol- $\mathrm{d}_{6}$ was purchased from Cambridge Isotope Laboratory. ${ }^{1} \mathrm{H},{ }^{13} \mathrm{C},{ }^{19} \mathrm{~F}, \mathrm{HSQC}$, and $\mathrm{HMBC}$ NMR spectra were recorded with an INOVA by Varian $\left(500 \mathrm{MHz}, 27^{\circ} \mathrm{C}\right)$ or with an Avance Neo by Bruker $\left(500 \mathrm{MHz}, 25^{\circ} \mathrm{C}\right)$. Recorded spectra were calibrated by solvent signals when applicable and processed with MestReNova software. High-resolution mass spectra were measured by Bruker microTOF-MS in both positive and negative ion modes. Sodium formate was used as a calibrant. IR spectra were measured with Alpha ATR-FTIR by Bruker. UV-vis spectra were recorded with Hewlett-Packard 8453 Spectrophotometer. A quartz cuvette (1 cm width) was used when acetone was used as solvent and a plastic cuvette when Milli-Q water was used as a solvent. The single-crystal X-ray diffraction was measured by Bruker 
D8 Venture diffractometer with a Photonll CPAD detector. Measurement was done at $123 \mathrm{~K}$ using $\mathrm{Cu}-\mathrm{K} \alpha$ radiation (1.541 $78 \AA$ A). Syntheses were conducted with a microwave synthesizer, either Initiator by Biotage or Monowave 450 by Anton Paar. Vials of $10 \mathrm{~mL}$ (2-5 mL (biotage), G10 (Anton-paar)) or $30 \mathrm{~mL}$ (10-20 mL (biotage, G30 (Anton-paar)) in total volume were used. Initiator vials have "cap with septum" and Monowave 450 vials have "snap cap" with "teflon-coated silicon septum" as caps. The temperature during synthesis was monitored by a surface IR sensor (Monowave 450 IR eye), which was calibrated with "Ruby thermometer" internal temperature probe. GC-MS spectra were recorded with Agilent 5973 equipped with 6890N MSD using HP5MSUI.

General Procedure for Diacid Salt Synthesis. Amino acid (2 mmol), NaOH, (10 mmol, $1.0 \mathrm{~mL}, 10 \mathrm{M})$, and tertbutanol/ corresponding alcohol mixture $(4.0 \mathrm{~mL}, 75 / 25 \mathrm{v} / \mathrm{v} \%)$ were added together with aromatic aldehyde (10 $\mathrm{mmol}$ ) to a $10 \mathrm{~mL}$ microwave vial. The reaction mixture often becomes solid after all reagents are added. Pressure fluctuation may occur during the heat up phase. Therefore, the heating program was set to heat the microwave vial to $135^{\circ} \mathrm{C}$ over $5 \mathrm{~min}$, and then temperature was maintained for $90 \mathrm{~min}$. Stirring speed was set to $600 \mathrm{rpm}$. Next, the microwave vial was cooled to $50^{\circ} \mathrm{C}$ by compressed air. Afterwards, isopropyl alcohol ( $2 \mathrm{~mL}$ ) was added into the microwave vial to initiate the crystallization overnight. The formed products were collected by filtration, washed with EtOH (with the exception of products 3, 7, and 11, see their own sections), and dried in air.

General Procedure for Protonated Diacids. The corresponding diacid salts were dissolved into water, and $1 \mathrm{M}$ $\mathrm{HCl}$ was added until all the products had precipitated from the solution. The powder was filtered, washed with water, and dried in vacuum. The reaction occurs instantaneously with near quantitative yields (>95\%).

General Procedure for $\delta$-Lactone Acid Synthesis. A solution of diacid ( $2 \mathrm{mmol}$ ), p-tolusulfonic acid monohydrate $\left(\mathrm{TsOH} \cdot \mathrm{H}_{2} \mathrm{O}, 2 \mathrm{mmol}\right.$ ) in toluene $(30 \mathrm{~mL})$ in a $50 \mathrm{~mL}$ flask was refluxed for $24 \mathrm{~h}$ using a Dean-Stark apparatus. Afterwards, the reaction solution was left to cool to room temperature for $2 \mathrm{~h}$, followed by removal of TsOH by filtration. The $\delta$-lactone acid product crystallized from the remaining toluene solution within 1-3 days. The solid products were collected by filtration, washed with toluene, and dried in vacuum.

2-Hydroxy-3,4-diphenylhexanedioic Acid Salt (Enantiomeric Pair of RRR and SSS) (1). A microwave vial (10 mL) containing L-phenylalanine ( $2 \mathrm{mmol}, 330.4 \mathrm{mg}$ ), benzaldehyde (10 mmol, $1015 \mu \mathrm{L}), \mathrm{NaOH}(10 \mathrm{mmol}, 1 \mathrm{~mL}, 10$ $\mathrm{M})$, and tert-butanol/ethanol mixture $(4 \mathrm{~mL}, 75 / 25 \mathrm{v} / \mathrm{v} \%)$ was heated to $135{ }^{\circ} \mathrm{C}$ over 5 min at a microwave reactor. Then the reaction temperature was maintained for $90 \mathrm{~min}$. The vial was cooled to $50{ }^{\circ} \mathrm{C}$ using compressed air. Isopropyl alcohol $(2 \mathrm{~mL})$ was added to the vial to initiate crystallization. The next day the formed powder was collected by filtration, washed with ethanol, and dried in air. The product was isolated as $554 \mathrm{mg}$ of a white powder (77\% yield calculated from amino acid). ${ }^{1} \mathrm{H} N \mathrm{NMR}\left(500 \mathrm{MHz}, \mathrm{D}_{2} \mathrm{O}\right): \delta 7.21-7.00(\mathrm{~m}, 10 \mathrm{H}), 4.57$ $(\mathrm{d}, \mathrm{J}=2.8 \mathrm{~Hz}, 1 \mathrm{H}), 3.71(\mathrm{ddd}, \mathrm{J}=11.4,4.5,11.4 \mathrm{~Hz}, 1 \mathrm{H}), 3.41(\mathrm{dd}, \mathrm{J}=11.6,2.8 \mathrm{~Hz}, 1 \mathrm{H}), 3.05$ (dd, J = 13.5, $4.4 \mathrm{~Hz}$, 1H), 2.54 (dd, J = 13.4, $11.3 \mathrm{~Hz}, 1 \mathrm{H}) .{ }^{13} \mathrm{C}\left\{{ }^{1} \mathrm{H}\right\} N M R(125 \mathrm{MHz}, \mathrm{D} 2 \mathrm{O}): \delta 181.5,179.9,143.6,139.2,130.0,128.8$, 128.1, 127.8, 126.5, 126.1, 72.4, 53.8, 44.2, 43.4. IR (atr): 3000-3500 (-OH, broad), 1573 (R-COONa, s), 1395 $(\mathrm{R}-\mathrm{OH}, \mathrm{s}), 1074(\mathrm{R}-\mathrm{C}(\mathrm{OH})-\mathrm{R}, \mathrm{m}), 698$ (Ph, s). UV-vis (Milli-Q water): $224 \mathrm{~nm}$ (shoulder), $258 \mathrm{~nm}$ (max), and 265

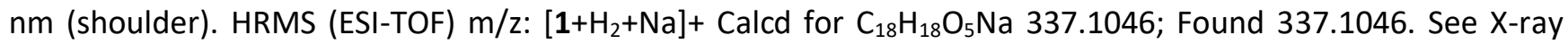
diffraction section for solved crystal structure of 1 (see Supporting Information S4.1 and S10.1). Cambridge Crystallographic Data Center number (CCDC): 1948055.

2-Hydroxy-3-(1H-indol-3-yl)-4-phenylhexanedioic Acid Salt (Enantiomeric Pair of RRR and SSS) (2). The product was synthesized according to the general procedure using L-tryptophan ( $2 \mathrm{mmol}, 408.5 \mathrm{mg}$ ) instead of Lphenylalanine. Product was isolated as $542 \mathrm{mg}$ of a white powder (68\% yield). ${ }^{1} \mathrm{H}$ NMR (500 MHz, D2O): $\delta 7.66$ $(\mathrm{m}, 1 \mathrm{H}), 7.30-6.90(\mathrm{~m}, 9 \mathrm{H}), 4.59(\mathrm{~d}, \mathrm{~J}=2.4 \mathrm{~Hz}, 1 \mathrm{H}), 3.81(\mathrm{dd}, \mathrm{J}=11.4,2.4 \mathrm{~Hz}, 1 \mathrm{H}), 3.73(\mathrm{ddd}, \mathrm{J}=11.2,4.3,11.3 \mathrm{~Hz}$, 
1H), 3.08 (dd, J = 13.5, $4.3 \mathrm{~Hz}, 1 \mathrm{H}), 2.59$ (dd, J = 13.4, 11.1 Hz, 1H). 13C $\{1 \mathrm{H}\}$ NMR (125 MHz, D2O): $\delta 181.7,180.3$, 144.2, 135.5, 128.5, 127.9, 127.7, 125.9, 124.8, 121.1, 120.0, 118.6, 112.7, 111.3, 72.4, 45.6, 45.3, 43.5. IR (atr): 3000-3800 (-OH, -N-H, broad), $1670(\mathrm{~N}-\mathrm{H}, \mathrm{m}), 1574$ (R-COONa, s), $1384(\mathrm{R}-\mathrm{OH}, \mathrm{s}), 1274(\mathrm{C}-\mathrm{N}, \mathrm{m}), 1083$ $(\mathrm{R}-\mathrm{C}(\mathrm{OH})-\mathrm{R}, \mathrm{s}), 704$ (Ph, s). UV-vis (Milli-Q water): $229 \mathrm{~nm}$ (shoulder), $282 \mathrm{~nm}$ (max), and $291 \mathrm{~nm}$ (shoulder). HRMS (ESI-TOF) m/z: [2+H $\left.\mathrm{H}_{2}+\mathrm{Na}\right]^{+}$Calcd for $\mathrm{C}_{20} \mathrm{H}_{19} \mathrm{NO}_{5} \mathrm{Na}$ 376.1155; Found 376.1147. See X-ray diffraction section for solved crystal structure of 2 (see Supporting Information S4.1 and S10.2). CCDC: 1948056.

2-Hydroxy-3-(4-hydroxyphenyl)-4-phenylhexanedioic Acid Salt (Enantiomeric Pair of RRR and SSS) (3). The product was synthesized according to the general procedure using L-tyrosine $(2 \mathrm{mmol}, 362.4 \mathrm{mg})$ instead of Lphenylalanine. Purification: The reaction solution was evaporated, and the crude solid was dissolved in $\mathrm{MeOH}$ and filtered. Acetone was added to the $\mathrm{MeOH}$ solution, precipitating the crude product. Recrystallization from water/acetone mixtures yielded pure $3(15 \mathrm{mg})$. According to ${ }^{1} \mathrm{H}$ NMR measurements, a $20 \%$ yield was obtained from the original reaction solution. ${ }^{1} \mathrm{H} N M R\left(500 \mathrm{MHz}, \mathrm{D}_{2} \mathrm{O}\right): \delta 7.21-7.12(\mathrm{~m}, 4 \mathrm{H}), 7.09-6.99(\mathrm{~m}, 3 \mathrm{H}), 6.60(\mathrm{~m}$, $2 \mathrm{H}$ ), $4.53(\mathrm{~d}, \mathrm{~J}=2.7 \mathrm{~Hz}, 1 \mathrm{H}), 3.63(\mathrm{ddd}, \mathrm{J}=11.5,11.4,4.4 \mathrm{~Hz}, 1 \mathrm{H}), 3.34(\mathrm{dd}, \mathrm{J}=11.6,2.8 \mathrm{~Hz}, 1 \mathrm{H}$ ), 3.02 (dd, J = 13.4, $4.4 \mathrm{~Hz}, 1 \mathrm{H}), 2.53(\mathrm{dd}, \mathrm{J}=13.4,11.4 \mathrm{~Hz}, 1 \mathrm{H}) .{ }^{13} \mathrm{C}\left\{{ }^{1} \mathrm{H}\right\}$ NMR $\left(125 \mathrm{MHz}, \mathrm{D}_{2} \mathrm{O}\right): \delta 181.4,179.7,153.7,143.5,131.0$, 130.9, 128.6, 127.9, 125.8, 114.4, 72.3, 52.7, 44.1, 43.1. IR (atr): 2800-3500 (-OH, broad), 1556 (-COONa, s), $1371(\mathrm{~s}), 1248(\mathrm{~s}), 700(\mathrm{~s})(\mathrm{Ph}-\mathrm{OH}), 1078(\mathrm{R}-\mathrm{HCOH}-\mathrm{R}(\mathrm{m})), 759(\mathrm{~m}), 733(\mathrm{~m})$ (R-Ph 5H adjacent), $522(\mathrm{w}), 465(\mathrm{~s})$ (R-Ph-R (2H adjacent)). UV-vis (Milli-Q water): $298 \mathrm{~nm}(\max )$ and $331 \mathrm{~nm}$ (shoulder). HRMS (ESI-TOF) m/z: $[3+\mathrm{H}]^{-}$Calcd for $\mathrm{C}_{18} \mathrm{H}_{17} \mathrm{O}_{6}$ 329.1020; Found 329.1026.

2-Hydroxy-3-phenyl-4-(4-methylphenyl)hexanedioic Acid Salt (Enantiomeric Pair of RRR and SSS) (4). The product was synthesized according to the general procedure using $p$-tolualdehyde $(10 \mathrm{mmol}, 1180 \mu \mathrm{L})$ instead of benzaldehyde. Product was isolated as $552 \mathrm{mg}$ of a white powder (74\% yield). ${ }^{1} \mathrm{H}$ NMR $\left(500 \mathrm{MHz}, \mathrm{D}_{2} \mathrm{O}\right): \delta$ 7.21-7.06 (m, 7H), 7.00-6.95 (m, 2H), $4.55(\mathrm{~d}, \mathrm{~J}=2.7 \mathrm{~Hz}, 1 \mathrm{H}), 3.66$ (ddd, J = 11.4, 4.3, $11.4 \mathrm{~Hz}, 1 \mathrm{H}), 3.37$ (dd, J = 11.5, $2.6 \mathrm{~Hz}, 1 \mathrm{H}), 3.03(\mathrm{dd}, \mathrm{J}=13.4,4.3 \mathrm{~Hz}, 1 \mathrm{H}), 2.52$ (dd, J = 13.2, $11.5 \mathrm{~Hz}, 1 \mathrm{H}), 2.14(\mathrm{~s}, 3 \mathrm{H}) .{ }^{13} \mathrm{C}\left\{{ }^{1} \mathrm{H}\right\} \mathrm{NMR}(125$ $\left.\mathrm{MHz}, \mathrm{D}_{2} \mathrm{O}\right): \delta 184.2,182.5,143.1,141.9,138.4,132.6,131.3,131.2,130.4,129.0,75.0,56.4,46.3,45.9,22.7 . \mathrm{IR}$ (atr): 2800-3200 (-OH, broad), 1612, 1543 (R-COONa, s), $1370\left(\mathrm{R}-\mathrm{OH}, \mathrm{s}, \mathrm{R}-\mathrm{CH}_{3}, \mathrm{~s}\right), 1093(\mathrm{R}-\mathrm{CH}(\mathrm{OH})-\mathrm{R}, \mathrm{m}), 825$ (2 adjacent $\mathrm{H}, \mathrm{Ph}, \mathrm{w}), 731(\mathrm{~m}), 703$ (s) (5 adjacent H, Ph). UV-vis (Milli-Q water): $258 \mathrm{~nm}$ (max), $265 \mathrm{~nm}(\max )$, $274 \mathrm{~nm}$ (max), $321 \mathrm{~nm}$ (shoulder), and $334 \mathrm{~nm}$ (shoulder). HRMS (ESI-TOF) m/z: [4+ $\left.\mathrm{H}_{2}+\mathrm{Na}\right]^{+} \mathrm{Calcd}$ for $\mathrm{C}_{19} \mathrm{H}_{20} \mathrm{O}_{5} \mathrm{Na}$ 351.1203; Found 351.1203.

2-Hydroxy-3-phenyl-4-(4-methoxyphenyl)hexanedioic Acid Salt (Enantiomeric Pair of RRR and SSS) (5). The product was synthesized according to the general procedure using $p$-anisaldehyde $(10 \mathrm{mmol}, 1215 \mu \mathrm{L})$ instead of benzaldehyde. Product was isolated as $265 \mathrm{mg}$ of a white powder ( $34 \%$ yield). ${ }^{1} \mathrm{H}$ NMR $\left(500 \mathrm{MHz}, \mathrm{D}_{2} \mathrm{O}\right): \delta$ 7.22-7.07 (m, 7H), 6.75-6.70 (m, 2H), $4.58(\mathrm{dd}, \mathrm{J}=2.8 \mathrm{~Hz}, 1 \mathrm{H}), 3.69(\mathrm{~m}, 4 \mathrm{H}), 3.39(\mathrm{dd}, \mathrm{J}=11.5,2.9 \mathrm{~Hz}, 1 \mathrm{H}), 3.06$ (dd, J = 13.4, 4.4 Hz, 1H), 2.54 (dd, J = 13.4, $11.4 \mathrm{~Hz}, 1 \mathrm{H}) .{ }^{13} \mathrm{C}\left\{{ }^{1} \mathrm{H}\right\}$ NMR $\left(125 \mathrm{MHz}, \mathrm{D}_{2} \mathrm{O}\right): \delta 184.2,182.5,159.4$, 141.9, 138.8, 132.6, 132.4, 130.4, 129.1, 116.1, 75.0, 57.9, 56.6, 46.0, 46.0. IR (atr): 2800-3500 (-OH, broad) 1612, 1555 ( $\mathrm{R}-\mathrm{COONa}, \mathrm{s}), 1371\left(-\mathrm{CH}_{3}, \mathrm{~s}\right), 1249(-\mathrm{OH}, \mathrm{s}), 1027(\mathrm{R}-\mathrm{CH}(\mathrm{OH})-\mathrm{R}, \mathrm{m}), 834$ (2 adjacent $\left.\mathrm{H}(\mathrm{Ph}), \mathrm{m}\right), 704$ (5 adjacent $\mathrm{H}(\mathrm{Ph}), \mathrm{s})$. UV-vis (Milli-Q water): $275 \mathrm{~nm}(\max )$ and $296 \mathrm{~nm}$ (shoulder). HRMS (ESI-TOF) m/z: $\left[5+\mathrm{H}_{2}+\mathrm{Na}\right]^{+} \mathrm{Calcd}$ for $\mathrm{C}_{19} \mathrm{H}_{20} \mathrm{O}_{6} \mathrm{Na}$ 367.1152; Found 367.1167. 
2-Hydroxy-3-phenyl-4-(4-chlorophenyl)hexanedioic Acid Salt (Enantiomeric Pair of RRR and SSS) (6). The product was synthesized according to the general procedure using 4-chloroben-zaldehyde $(10 \mathrm{mmol}, 1240 \mathrm{mg})$ instead of benzaldehyde. Product was isolated as $334 \mathrm{mg}$ of a white powder (43\% yield). $\left.{ }^{1} \mathrm{H} \mathrm{NMR} \mathrm{(500} \mathrm{MHz,} \mathrm{D}_{2} \mathrm{O}\right): \delta$ 7.21-7.09 (m, 9H), $4.58(\mathrm{~d}, \mathrm{~J}=2.8 \mathrm{~Hz}, 1 \mathrm{H}), 3.72(\mathrm{td}, \mathrm{J}=11.5,4.5,11.5 \mathrm{~Hz}, 1 \mathrm{H}), 3.38(\mathrm{dd}, \mathrm{J}=11.6,2.9 \mathrm{~Hz}, 1 \mathrm{H}), 3.07$ (dd, J = 13.5, 4.4 Hz, 1H), 2.55 (dd, J = 13.4, $11.4 \mathrm{~Hz}, 1 \mathrm{H}) .{ }^{13} \mathrm{C}\left\{{ }^{1} \mathrm{H}\right\} \mathrm{NMR}\left(125 \mathrm{MHz}, \mathrm{D}_{2} \mathrm{O}\right): \delta$ 183.9, 182.4, 144.8, 141.6, 133.6, 132.8, 132.6, 130.6, 130.4, 129.1, 74.9, 56.4, 46.3, 45.8. IR (atr): 2800-3500 (-OH, broad), 1614, $1556(\mathrm{R}-\mathrm{COONa}, \mathrm{s}), 1370(\mathrm{R}-\mathrm{CH}(\mathrm{OH})-\mathrm{R}, \mathrm{s}), 1093$ ( $\mathrm{Ar}-\mathrm{Cl} / \mathrm{R}-\mathrm{CH}(\mathrm{OH})-\mathrm{R}), \mathrm{s}), 829$ (2 adjacent $\mathrm{H}(\mathrm{Ph}), \mathrm{m}), 702$ (5 adjacent $\mathrm{H}$ (Ph), s). UV-vis (Milli-Q water): $257 \mathrm{~nm}$ (max), $260 \mathrm{~nm}$ (max), and $278 \mathrm{~nm}$ (shoulder). HRMS (ESI-TOF) $\mathrm{m} / \mathrm{z}:\left[6+\mathrm{H}_{2}+\mathrm{Na}\right]^{+}$Calcd for $\mathrm{C}_{18} \mathrm{H}_{17} \mathrm{ClO}_{5} \mathrm{Na} 371.0657$; Found 371.0654.

2-Hydroxy-3-phenyl-4-(4-fluorophenyl)hexanedioic Acid Salt (Enantiomeric Pair of RRR and SSS) (7). The product was synthesized according to the general procedure using 4-fluorobenzal-dehyde $(10 \mathrm{mmol}, 1070 \mu \mathrm{L})$ instead of benzaldehyde. Characterization data is reported for crude 7 , because purification was difficult. For corresponding pure acid $7 \mathrm{H}_{2}$ please see section below. (Corresponding pure $7 \mathrm{H}_{2}(195 \mathrm{mg}, 26 \%$ yield) is reported later in the Experimental Section.) ${ }^{1} \mathrm{H}$ NMR $\left(500 \mathrm{MHz}, \mathrm{D}_{2} \mathrm{O}\right): \delta 7.18-7.06(\mathrm{~m}, 7 \mathrm{H}), 6.87-6.81(\mathrm{~m}, 2 \mathrm{H}), 4.56(\mathrm{~d}, \mathrm{~J}=2.8 \mathrm{~Hz}, 1 \mathrm{H})$, $3.69(\mathrm{td}, \mathrm{J}=11.6,4.4 \mathrm{~Hz}, 1 \mathrm{H}), 3.36(\mathrm{dd}, \mathrm{J}=11.6,2.9 \mathrm{~Hz}, 1 \mathrm{H}), 3.05(\mathrm{dd}, \mathrm{J}=13.4,4.4 \mathrm{~Hz}, 1 \mathrm{H}), 2.51$ (dd, J = 13.4, 11.5 $\mathrm{Hz}, 1 \mathrm{H}) .{ }^{13} \mathrm{C}\left\{{ }^{1} \mathrm{H}\right\}$ NMR $\left(125 \mathrm{MHz}, \mathrm{D}_{2} \mathrm{O}\right): \delta 181.2,179.6,161.7,159.8,139.0,139.0,138.9,130.0,129.9,129.8$, 127.6, 126.3, 114.5, 114.3, 72.1, 53.7, 43.3, 43.2. $\left.{ }^{19} \mathrm{~F} \mathrm{NMR} \mathrm{(470} \mathrm{MHz,} \mathrm{D}_{2} \mathrm{O}\right): \delta-118.0$. IR (atr): $2800-3500(-\mathrm{OH}$, broad), $1605(\mathrm{~m}), 1552(\mathrm{~m}), 1390(\mathrm{~m})(-\mathrm{COONa}) 1220(\mathrm{~m}), 1100(\mathrm{w})(\mathrm{R}-\mathrm{CHOH}-\mathrm{R}), 839(\mathrm{w}), 791(\mathrm{w})(\mathrm{R}-\mathrm{Ph}-\mathrm{R}(2 \mathrm{H}$ adjacent)), $761(\mathrm{w}), 728(\mathrm{w}), 705(\mathrm{~m})$ (R-Ph (5H adjacent)), $663(\mathrm{~m}), 523(\mathrm{~s})(\mathrm{C}-\mathrm{F})$. UV-vis (Milli-Q water): $289 \mathrm{~nm}$ (max) and $298 \mathrm{~nm}$ (shoulder). HRMS (ESI-TOF) m/z: [7+H] $]^{-}$Calcd for $\mathrm{C}_{18} \mathrm{H}_{16} \mathrm{FO}_{5}$ 331.0976; Found 331.0976.

2-Hydroxy-3-phenyl-4-(3-methylphenyl)hexanedioic Acid Salt (Enantiomeric Pair of RRR and SSS) (8). The product was synthesized according to the general procedure using $m$-tolualdehyde (10 $\mathrm{mmol}, 1180 \mu \mathrm{L})$ instead of benzaldehyde. Product was isolated as $364 \mathrm{mg}$ of a white powder (49\% yield). ${ }^{1} \mathrm{H}$ NMR $\left(500 \mathrm{MHz}, \mathrm{D}_{2} \mathrm{O}\right): \delta$ 7.22-7.18 (m, 2H), 7.17-7.13 (m, 2H), 7.11-6.99 (m, 4H), $6.89(\mathrm{~m}, 1 \mathrm{H}), 4.58(\mathrm{~d}, \mathrm{~J}=2.7 \mathrm{~Hz}, 1 \mathrm{H}), 3.69(\mathrm{ddd}, \mathrm{J}=11.4$, 4.4, $11.4 \mathrm{~Hz}, 1 \mathrm{H}), 3.43(\mathrm{dd}, \mathrm{J}=11.6,2.8 \mathrm{~Hz}, 1 \mathrm{H}), 3.05$ (dd, J = 13.5, $4.4 \mathrm{~Hz}, 1 \mathrm{H}), 2.54(\mathrm{dd}, \mathrm{J}=13.4,11.3 \mathrm{~Hz}, 1 \mathrm{H})$, $2.20(\mathrm{~s}, 3 \mathrm{H}) .{ }^{13} \mathrm{C}\left\{{ }^{1} \mathrm{H}\right\}$ NMR $\left(125 \mathrm{MHz}, \mathrm{D}_{2} \mathrm{O}\right): \delta 181.6,179.9,143.7,139.2,138.0,130.0,129.5,128.0,127.8,126.6$, 126.5, 125.8, 72.4, 53.7, 44.0, 43.4, 20.5. IR (atr): 1610, 1572, 1402 (R-COONa, s), $1376\left(-\mathrm{CH}_{3}, \mathrm{~s}\right), 1102$ $(\mathrm{R}-\mathrm{CH}(\mathrm{OH})-\mathrm{R}, \mathrm{m}), 758$ ( 3 adjacent $\mathrm{H}(\mathrm{Ph}), \mathrm{m}), 694$ (5 adjacent $\mathrm{H}(\mathrm{Ph}), \mathrm{s})$. UV-vis (Milli-Q water): $258 \mathrm{~nm}$ (max),

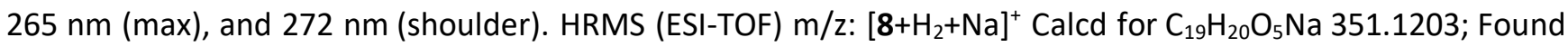
351.1209 .

2-Hydroxy-3-phenyl-4-(2-methylphenyl)hexanedioic Acid Salt (Enantiomeric Pair of RRR and SSS) (9). The product was synthesized according to the general procedure using $o$-tolualdehyde (10 mmol, $1160 \mu \mathrm{L}$ ) instead of benzaldehyde. Product was isolated as $312 \mathrm{mg}$ of a white powder (41\% yield). ${ }^{1} \mathrm{H} \mathrm{NMR}\left(500 \mathrm{MHz}, \mathrm{D}_{2} \mathrm{O}\right): \delta 7.43$ $(\mathrm{d}, \mathrm{J}=6.2 \mathrm{~Hz}, 1 \mathrm{H}), 7.21(\mathrm{~m}, 2 \mathrm{H}), 7.16-7.05(\mathrm{~m}, 4 \mathrm{H}), 6.98-6.91(\mathrm{~m}, 2 \mathrm{H}), 4.60(\mathrm{~d}, \mathrm{~J}=2.7 \mathrm{~Hz}, 1 \mathrm{H}), 4.06(\mathrm{dd}, \mathrm{J}=11.1$, $4.4 \mathrm{~Hz}, 1 \mathrm{H}), 3.43(\mathrm{dd}, \mathrm{J}=11.3,2.0 \mathrm{~Hz}, 1 \mathrm{H}), 3.03(\mathrm{dd}, \mathrm{J}=13.0,4.4 \mathrm{~Hz}, 1 \mathrm{H}), 2.50(\mathrm{t}, \mathrm{J}=12.0 \mathrm{~Hz}, 1 \mathrm{H}), 2.23(\mathrm{~s}, 3 \mathrm{H})$. ${ }^{13} \mathrm{C}\left\{{ }^{1} \mathrm{H}\right\}$ NMR $\left(125 \mathrm{MHz}, \mathrm{D}_{2} \mathrm{O}\right): \delta$ 181.4, 179.7, 142.2, 139.5, 136.6, 129.7, 129.5, 127.5, 127.1, 126.4, 125.9, 125.7, 72.3, 54.0, 43.3, 38.4, 19.2. IR (atr): 3400-2800 (-OH, broad) 1614, 1604, 1401 (R-COONa, s), $1379\left(-\mathrm{CH}_{3}, \mathrm{~m}\right)$, $1102(\mathrm{R}-\mathrm{CH}(\mathrm{OH})-\mathrm{R}, \mathrm{m}), 764$ (4 adjacent $\mathrm{H}(\mathrm{Ph}), \mathrm{m})$, 730, 702 (5 adjacent H (Ph), s). UV-vis (Milli-Q water): 259 
$\mathrm{nm}$ (max), $265 \mathrm{~nm}(\max )$, and $273 \mathrm{~nm}$ (shoulder). HRMS (ESI-TOF) m/z: $\left[9+\mathrm{H}_{2}+\mathrm{Na}\right]^{+}$Calcd for $\mathrm{C}_{19} \mathrm{H}_{20} \mathrm{O}_{5} \mathrm{Na}$ 351.1203; Found 351.1208.

2-Hydroxy-5-methyl-3,4-diphenylhexanedioic Acid Salt (Enantiomeric Pair of RRRR and SSSS) (10). The product was synthesized according to the general procedure using tert-butanol/1-propanol ( $4 \mathrm{~mL}, 75 / 25 \mathrm{v} / \mathrm{v} \%)$ instead of tert-butanol/ethanol mixture. Product was isolated as $396 \mathrm{mg}$ of a white powder (53\% yield). ${ }^{1} \mathrm{H}$ NMR (500 $\left.\mathrm{MHz}, \mathrm{D}_{2} \mathrm{O}\right):$ : $7.25-7.21(\mathrm{~m}, 2 \mathrm{H}), 7.18-7.10(\mathrm{~m}, 6 \mathrm{H}), 7.07-7.02(\mathrm{~m}, 2 \mathrm{H}), 4.54(\mathrm{~d}, \mathrm{~J}=2.6 \mathrm{~Hz}, 1 \mathrm{H}), 3.95$ (dd, J = 12.0, $4.5 \mathrm{~Hz}, 1 \mathrm{H}), 3.73(\mathrm{dd}, \mathrm{J}=12.1,2.7 \mathrm{~Hz}, 1 \mathrm{H}), 3.08(\mathrm{dq}, \mathrm{J}=7.1,4.6 \mathrm{~Hz}, 1 \mathrm{H}), 1.05(\mathrm{~d}, \mathrm{~J}=7.0 \mathrm{~Hz}, 3 \mathrm{H}) .{ }^{13} \mathrm{C}\left\{{ }^{1} \mathrm{H}\right\} \mathrm{NMR}(125$ $\left.\mathrm{MHz}, \mathrm{D}_{2} \mathrm{O}\right): \delta 187.2,182.5,142.9,141.9,132.8,132.7,130.4,130.3,129.1,128.8,75.0,52.0,50.4,46.7,13.9$. IR (atr): 2800-3500 (-OH, broad), 1593, 1537 (R- COONa, m), $1450\left(\mathrm{R}-\mathrm{CH}_{3}, \mathrm{~m}\right), 1397(\mathrm{R}-\mathrm{CH}(\mathrm{OH})-\mathrm{R}, \mathrm{m}), 1378$ $\left(\mathrm{R}-\mathrm{CH}_{3}, \mathrm{~m}\right), 1281,1076(\mathrm{R}-\mathrm{CH}(\mathrm{OH})-\mathrm{R}, \mathrm{m}), 699$ (5 adjacent $\left.\mathrm{H}(\mathrm{Ph}), \mathrm{s}\right)$. UV-vis (Milli-Q water): 259 (max) and 264 (max). HRMS (ESI-TOF) m/z: [10+ $\left.\mathrm{H}_{2}+\mathrm{Na}\right]^{+}$Calcd for $\mathrm{C}_{19} \mathrm{H}_{20} \mathrm{O}_{5} \mathrm{Na}$ 351.1203; Found 351.1207.

2-Hydroxy-5-ethyl-3,4-diphenylhexanedioic Acid Salt (Enantiomeric Pair of RRRR and SSSS) (11). The product was synthesized according to the general procedure using tert-butanol/1-butanol ( $4 \mathrm{~mL}, 75 / 25 \mathrm{v} / \mathrm{v} \%$ ) instead of tertbutanol/ethanol mixture. Purification: The crude product was washed with isopropyl alcohol and dissolved into $\mathrm{EtOH}$. The EtOH solution was added into another isopropyl alcohol solution. Crystals formed overnight at isopropyl alcohol-ethanol solution. Product was isolated as $173 \mathrm{mg}$ of a white needle crystals (22\% yield). ${ }^{1} \mathrm{H}$ NMR (500 MHz, $\left.\mathrm{D}_{2} \mathrm{O}\right): \delta$ 7.21-7.18 (m, 2H), 7.14-7.10 (m, 6H), 7.08-7.02 (m, 2H), $4.53(\mathrm{~d}, \mathrm{~J}=2.6 \mathrm{~Hz}, 1 \mathrm{H}), 3.76$ (dd, J = 11.4, 4.6 Hz, 1H), 3.75 (dd, J = 11.5, 2.7 Hz, 1H), 2.79 (ddd, J = 11.9, 4.7, $2.6 \mathrm{~Hz}, 1 \mathrm{H}$ ), 1.62 (dqd, J = 14.8, 7.4, $2.6 \mathrm{~Hz}, 1 \mathrm{H}), 1.35(\mathrm{~m}, 1 \mathrm{H}), 0.87(\mathrm{t}, \mathrm{J}=7.3 \mathrm{~Hz}, 3 \mathrm{H}) .{ }^{13} \mathrm{C}\left\{{ }^{1} \mathrm{H}\right\} \mathrm{NMR}\left(125 \mathrm{MHz}, \mathrm{D}_{2} \mathrm{O}\right): \delta 186.1,182.5,143.5,141.9$, 132.8, 132.6, 130.3, 130.3, 129.0, 128.7, 75.2, 55.7, 52.8, 51.0, 22.2, 15.0. IR (atr): 2800-3200 (-OH, broad), 1591 ( $\mathrm{R}-\mathrm{COONa}, \mathrm{s}), 1449$ (- $\left.\mathrm{CH}_{2}-\mathrm{or}-\mathrm{CH}_{3}, \mathrm{~m}\right), 1380$ (R-Me, s), 1378 (s), 1448 (s) (R-COONa), $1080(\mathrm{R}-\mathrm{CH}(\mathrm{OH})-\mathrm{R}, \mathrm{m})$, 701 (5 adjacent $\mathrm{H}(\mathrm{Ph})$ ). UV-vis (Milli-Q water): $259 \mathrm{~nm}$ (max), $264 \mathrm{~nm}$ (shoulder), and $293 \mathrm{~nm}$ (shoulder). HRMS (ESI-TOF) m/z: [11+ $\left.\mathrm{H}_{2}+\mathrm{Na}\right]^{+}$Calcd for $\mathrm{C}_{20} \mathrm{H}_{22} \mathrm{O}_{5} \mathrm{Na}$ 365.1359; Found 365.1352.

2-Hydroxy-3,4,5-triphenylhexanedioic Acid Salt (Enantiomeric Pair of 2R, 3R, 4S, $5 S$ and 2S, 3S, 4R, 5R) (12). The product was synthesized according to the general procedure using tert-butanol/2-phenylethanol $(4 \mathrm{~mL}, 75 / 25$ $\mathrm{v} / \mathrm{v} \%$ ) instead of tert-butanol/ethanol mixture. Product was isolated as $458 \mathrm{mg}$ of a white powder (53\% yield). ${ }^{1} \mathrm{H}$ NMR $\left(500 \mathrm{MHz}, \mathrm{D}_{2} \mathrm{O}\right):$ : 7.22-7.08 (m, 9H), 7.05-7.01 (m, 1H), 6.97-6.91 (m, 4H), 6.88-6.84 (m, 1H), $4.54(\mathrm{~d}$, $\mathrm{J}=4.6 \mathrm{~Hz}, 1 \mathrm{H}), 4.21(\mathrm{dd}, \mathrm{J}=10.5,8.2 \mathrm{~Hz}, 1 \mathrm{H}), 3.98(\mathrm{~d}, \mathrm{~J}=10.5 \mathrm{~Hz}, 1 \mathrm{H}), 3.60(\mathrm{dd}, \mathrm{J}=8.2,4.6 \mathrm{~Hz}, 1 \mathrm{H}) .{ }^{13} \mathrm{C}\left\{{ }^{1} \mathrm{H}\right\} \mathrm{NMR}$ (125 MHz, D ${ }_{2}$ ): $\delta$ 181.7, 179.6, 141.0, 140.5, 138.7, 130.7, 129.2, 127.9, 127.3, 127.1, 126.3, 126.1, 125.5, 73.7, $59.5,54.1,48.6$. (130.7 or 127.9 is double peak, too low resolution to tell the difference). IR (atr): $3500-3200$ (-OH, broad), 1623 (s), 1599 (s), 1549 (s) (-COONa), 1374(s), 1096(w), 1071(w) (R-CH(OH)-R), 694 (5 adjacent $\mathrm{H}(\mathrm{Ph})$ ). UV-vis (Milli-Q water): $299 \mathrm{~nm}$ (max). HRMS (ESI-TOF) m/z: [12+H] ${ }^{-}$Calcd for $\mathrm{C}_{24} \mathrm{H}_{21} \mathrm{O}_{5} 389.1384$; Found 389.1384 . 
2-Hydroxy-3-(isopropyl alcohol)-4-phenylhexanedioic Acid Salt (Enantiomeric Pair of 2R, 3S, $4 R$ and 2S, 3R, 4S) (13). The product was synthesized according to the general procedure using L-leucine ( $2 \mathrm{mmol}, 262.4 \mathrm{mg}$ ) instead of L-phenylalanine. Product was isolated as $117 \mathrm{mg}$ of a white powder (18\% yield). ${ }^{1} \mathrm{H} \mathrm{NMR}\left(500 \mathrm{MHz}, \mathrm{D}_{2} \mathrm{O}\right): \delta$ 7.40-7.36 (m, 4H), $7.27(\mathrm{~m}, 1 \mathrm{H}), 4.03(\mathrm{~d}, \mathrm{~J}=1.7 \mathrm{~Hz}, 1 \mathrm{H}), 3.52$ (ddd, J = 12.2, 6.6, $4.1 \mathrm{~Hz}, 1 \mathrm{H}), 2.74$ (dd, J = 14.7, $4.1 \mathrm{~Hz}, 1 \mathrm{H}), 2.62(\mathrm{dd}, \mathrm{J}=14.6,12.3 \mathrm{~Hz}, 1 \mathrm{H}), 2.11$ (ddd, J = 1.7, 6.7, $6.7 \mathrm{~Hz}, 1 \mathrm{H}), 1.78(\mathrm{~m}, 1 \mathrm{H}), 1.05(\mathrm{~d}, \mathrm{~J}=6.9 \mathrm{~Hz}$, $3 \mathrm{H}), 0.78(\mathrm{~d}, \mathrm{~J}=6.9 \mathrm{~Hz}, 3 \mathrm{H}) .{ }^{13} \mathrm{C}\left\{{ }^{1} \mathrm{H}\right\} \mathrm{NMR}\left(125 \mathrm{MHz}, \mathrm{D}_{2} \mathrm{O}\right): \delta 182.4,182.2,144.8,128.5,128.3,126.1,71.4,52.1$, 42.5, 39.0, 26.9, 20.79, 20.77. IR (atr): 3500-3200 (-OH, broad), 1602(s), 1556(s), 1362(m) (-COONa), 1403 (s), $1319(\mathrm{~m}), 1288(\mathrm{~m})(\mathrm{R}-\mathrm{CH}(\mathrm{OH})-\mathrm{R}), 697(\mathrm{~s}), 516(\mathrm{~m})$ (5 adjacent $\mathrm{H}(\mathrm{Ph})$ ). UV-vis (Milli-Q water): $288 \mathrm{~nm}(\mathrm{max})$ and $293 \mathrm{~nm}$ (shoulder). HRMS (ESI-TOF) m/z: [13+H] $]^{-}$Calcd for $\mathrm{C}_{15} \mathrm{H}_{19} \mathrm{O}_{5}$ 279.1227; Found 279.1227.

5-Carboxylic Acid-3,4-diphenyl- $\delta$-valorelactone (Enantiomeric Pair of RRR and SSS) (14). A toluene (30 mL) solution of $\mathbf{1 H}_{\mathbf{2}}(2 \mathrm{mmol}, 628.7 \mathrm{mg})$ and $\mathrm{TsOH}(2 \mathrm{mmol}, 380.4 \mathrm{mg})$ was refluxed for $24 \mathrm{~h}$ using a Dean-Stark apparatus. Afterwards, the reaction solution was left to cool to room temperature for $2 \mathrm{~h}$, followed by removal of $\mathrm{TsOH}$ by filtration. Product 14 precipitated out from the remaining toluene solution during the following day. Next, the product was collected by filtration, washed with toluene, and dried in vacuum. Product 14 was isolated as $484 \mathrm{mg}$ of a white powder (81\% yield). ${ }^{1} \mathrm{H}$ NMR $\left(500 \mathrm{MHz}\right.$, acetone- $\left.\mathrm{d}_{6}\right): \delta 7.35-7.32(\mathrm{~m}, 2 \mathrm{H}), 7.28-7.14(\mathrm{~m}$, $8 \mathrm{H}), 5.32(\mathrm{~d}, \mathrm{~J}=5.5 \mathrm{~Hz}, 1 \mathrm{H}), 3.97(\mathrm{dd}, \mathrm{J}=10.4,5.5 \mathrm{~Hz}, 1 \mathrm{H}), 3.81(\mathrm{td}, \mathrm{J}=10.5,6.4 \mathrm{~Hz}, 1 \mathrm{H}), 2.92(\mathrm{~m}, 2 \mathrm{H}) .{ }^{13} \mathrm{C}\left\{{ }^{1} \mathrm{H}\right\}$ NMR $\left(125 \mathrm{MHz}\right.$, acetone- $\left.\mathrm{d}_{6}\right): \delta$ 170.0, 169.9, 143.3, 138.5, 129.8, 129.5, 129.1, 128.4, 128.1, 127.7, 80.0, 48.3, 41.8, 38.6. IR (atr): 3000-2500 (-COOH, broad), 1730(s), 1204(s), 1160(s), 832(s) (R-O-CO-R), 1681 (s), 1416 (w), 1087 (s), 905 (m) (R-COOH), $1493\left(\mathrm{R}-\mathrm{CH}_{2}-\mathrm{R}, \mathrm{w}\right) 695$ (Ph, 5 adjacent H). UV-vis (acetone): $207 \mathrm{~nm}$ (max), $210 \mathrm{~nm}$ (max), $212 \mathrm{~nm}(\max ), 217 \mathrm{~nm}$ (shoulder), and $336 \mathrm{~nm}(\max )$. HRMS (ESI-TOF) m/z: Monomer [14+Na] ${ }^{+}$Calcd for $\mathrm{C}_{18} \mathrm{H}_{16} \mathrm{O}_{4} \mathrm{Na}$ 319.0941; Found 319.0938; Dimer [2×14+Na] ${ }^{+}$Calcd for $\mathrm{C}_{36} \mathrm{H}_{32} \mathrm{O}_{8} \mathrm{Na}$ 615.1989; Found 615.2006.

5-Carboxylic Acid-4-(1H-indol-3-yl)-3-phenyl- $\delta$-valorelactone (Enantiomeric Pair of RRR and SSS) (15). A toluene $(15 \mathrm{~mL})$ solution of $2 \mathrm{H}_{\mathbf{2}}(1 \mathrm{mmol}, 353.4 \mathrm{mg})$ and $\mathrm{HCl}(1 \mathrm{mmol}, 1 \mathrm{~mL}, 1 \mathrm{M})$ was refluxed for $24 \mathrm{~h}$ using a Dean-Stark apparatus. Afterwards, the reaction solution was left to cool to room temperature. The product precipitated out from the toluene solution in a few hours. Next, the product was collected by filtration, washed with toluene, and dried in vacuum. Product 15 was isolated as $291 \mathrm{mg}$ of a white powder ( $86 \%$ yield). ${ }^{1} \mathrm{H}$ NMR ( $500 \mathrm{MHz}$, acetone$\left.d_{6}\right): \delta 7.68(d, J=7.9 \mathrm{~Hz}, 1 \mathrm{H}), 7.42(\mathrm{~d}, \mathrm{~J}=7.5 \mathrm{~Hz}, 2 \mathrm{H}), 7.34(\mathrm{~d}, \mathrm{~J}=8.1 \mathrm{~Hz}, 1 \mathrm{H}), 7.28(\mathrm{t}, \mathrm{J}=7.6 \mathrm{~Hz}, 2 \mathrm{H}), 7.18(\mathrm{~m}, 2 \mathrm{H})$, $7.09(\mathrm{t}, \mathrm{J}=7.5 \mathrm{~Hz}, 1 \mathrm{H}), 7.03(\mathrm{t}, \mathrm{J}=7.4 \mathrm{~Hz}, 1 \mathrm{H}), 5.36(\mathrm{~d}, \mathrm{~J}=5.0 \mathrm{~Hz}, 1 \mathrm{H}), 4.27(\mathrm{dd}, \mathrm{J}=9.2,5.0 \mathrm{~Hz}, 1 \mathrm{H}), 3.89(\mathrm{td}, \mathrm{J}=$ 9.2, 6.9 Hz, 1H), $2.93(\mathrm{~m}, 2 \mathrm{H}) .{ }^{13} \mathrm{C}\left\{{ }^{1} \mathrm{H}\right\}$ NMR $\left(125 \mathrm{MHz}\right.$, acetone- $\left.\mathrm{d}_{6}\right): \delta 170.4,170.0,144.2,137.2,129.6,128.2$, 128.0, 127.7, 124.3, 122.4, 119.9, 119.2, 112.3, 111.7, 79.2, 41.9, 39.7, 37.9. IR (atr): 3400-3200 (NH, broad), 1735 (s), 1405 (m), 939 (m) (R-COOH), 1495 (indole, w), $1458\left(\mathrm{R}-\mathrm{CH}_{2}-\mathrm{R}, \mathrm{m}\right), 1213$ (s), 1106 (s), 1067 (s) (R-O-CO-R), 740 (s), 694 (s) (Ph, 5 adjacent H). UV-vis (EtOH): $291 \mathrm{~nm}$ (max) and $299 \mathrm{~nm}$ (max). HRMS (ESITOF) m/z: Monomer [15+Na] ${ }^{+}$Calcd for $\mathrm{C}_{20} \mathrm{H}_{17} \mathrm{NO}_{4} \mathrm{Na}$ 358.1050; Found 358.1050; Dimer [2×15+Na] ${ }^{+}$Calcd for $\mathrm{C}_{40} \mathrm{H}_{34} \mathrm{~N}_{2} \mathrm{O}_{8} \mathrm{Na}$ 693.2207; Found 693.2208.

5-Carboxylic Acid-3-(4-methylphenyl)-4-phenyl- $\delta$-valorelactone (Enantiomeric Pair of RRR and SSS) (16). The product was synthesized according to the general procedure using $\mathbf{4} \mathbf{H}_{\mathbf{2}}(2 \mathrm{mmol}, 656.7 \mathrm{mg}$ ) with additional TsOH $(4 \mathrm{mmol}, 760.9 \mathrm{mg})$ and a prolonged reaction time $(48 \mathrm{~h})$. The product was isolated as $149 \mathrm{mg}$ of a white powder (24\% yield). ${ }^{1} \mathrm{H}$ NMR (500 MHz, acetone-d6): $\delta$ 7.28-7.25 (m, 2H), 7.24-7.19 (m, 4H), 7.18-7.14 (m, 1H), 7.08- 
$7.04(\mathrm{~m}, 2 \mathrm{H}), 5.30(\mathrm{~d}, \mathrm{~J}=5.4 \mathrm{~Hz}, 1 \mathrm{H}), 3.93(\mathrm{dd}, \mathrm{J}=5.4,10.4 \mathrm{~Hz}, 1 \mathrm{H}), 3.76(\mathrm{td}, \mathrm{J}=10.5,6.4 \mathrm{~Hz}, 1 \mathrm{H}), 2.91(\mathrm{~m}, 2 \mathrm{H})$, $2.22(\mathrm{~s}, 3 \mathrm{H}) .{ }^{13} \mathrm{C}\left\{{ }^{1} \mathrm{H}\right\}$ NMR $(125 \mathrm{MHz}$, acetone-d6): $\delta 170.02,169.98,140.4,138.6,137.1,130.2,129.8,129.1$, 128.2, 128.1, 80.0, 48.4, 41.5, 38.7, 20.9. IR (atr): 3200-2800 (-COOH, broad), 1733(s), 1049(s) (R-O-CO-R), 1686 (s), 1193 (s), 1085 (s) (R-COOH), 1415 (w, R-CH $-\mathrm{R}), 1386(\mathrm{~m}), 822$ (m) (R-Ph-p-me), 746 (s), 695 (s) (Ph, 5 adjacent $\mathrm{H}$ ). UV-vis (acetone): $210 \mathrm{~nm}$ (max), $212 \mathrm{~nm}$ (shoulder), $216 \mathrm{~nm}$ (max), and $332 \mathrm{~nm}$ (max). HRMS (ESITOF) m/z: Monomer [16+Na] ${ }^{+}$Calcd for $\mathrm{C}_{19} \mathrm{H}_{18} \mathrm{O}_{4} \mathrm{Na}$ 333.1097; Found 333.1098; Dimer [2×16+Na] $]^{+}$Calcd for $\mathrm{C}_{38} \mathrm{H}_{36} \mathrm{O}_{8} \mathrm{Na}$ 643.2302; Found 643.2312.

5-Carboxylic Acid-2-methyl-3,4-diphenyl- $\delta$-valorelactone (Enantiomeric Pair of RRRR and SSSS) (17). The product was synthesized according to the general procedure using $\mathbf{1 0 H}_{\mathbf{2}}(2 \mathrm{mmol}, 656.7 \mathrm{mg})$. The product was isolated as a white powder $71 \%\left(432 \mathrm{mg}\right.$ ) yield. ${ }^{1} \mathrm{H} N \mathrm{NMR}\left(500 \mathrm{MHz}\right.$, acetone- $\left.\mathrm{d}_{6}\right): \delta 7.35-7.26(\mathrm{~m}, 4 \mathrm{H}) 7.22-7.15(\mathrm{~m}, 6 \mathrm{H}), 5.49$ $(\mathrm{d}, \mathrm{J}=5.4 \mathrm{~Hz}, 1 \mathrm{H}), 3.92(\mathrm{dd}, \mathrm{J}=8.7,5.4 \mathrm{~Hz}, 1 \mathrm{H}), 3.24-3.13(\mathrm{~m}, 2 \mathrm{H}), 1.06(\mathrm{~d}, \mathrm{~J}=6.2 \mathrm{~Hz}, 3 \mathrm{H}) .{ }^{13} \mathrm{C}\left\{{ }^{1} \mathrm{H}\right\} \mathrm{NMR}(125 \mathrm{MHz}$, acetone- $\left.\mathrm{d}_{6}\right): \delta 173.6,169.5,143.0,139.6,129.6,129.5,129.1,128.9,128.0,127.8,78.7,51.1,50.5,42.0,14.5$. IR (atr): 3600-3300 (-OH, broad), 3100-2800 (R-COOH, broad), 1731 (s), 1225 (s), 1187 (s), $1088(\mathrm{~s}), 775$ (m), 761 (m) (R-O-(HCO)-R), 1454 (w, R-CH $), 1412(\mathrm{~m}), 527$ (s) (R-COOH), 699 (s), 438 (s) (Ph). UV-vis (acetone): 208 nm (max), 214 nm (max), 217 nm (shoulder), and 338 nm (max). HRMS (ESI-TOF) m/z: Monomer [17-H] ${ }^{-}$Calcd for $\mathrm{C}_{19} \mathrm{H}_{17} \mathrm{O}_{4}$ 309.1121; Found 309.1117; Dimer [2×17-H] ${ }^{-}$Calcd for $\mathrm{C}_{38} \mathrm{H}_{35} \mathrm{O}_{8}$ 619.2326; Found 619.2323.

2-Hydroxy-3,4-diphenylhexanedioic Acid (Enantiomeric Pair of RRR and SSS) $\left(\mathbf{1}_{\mathbf{2}}\right)$. The product was synthesized according to the general procedure for protonated diacids from product $1 .{ }^{1} \mathrm{H} \mathrm{NMR}\left(500 \mathrm{MHz}\right.$, acetone- $\left.\mathrm{d}_{6}\right): \delta$ 7.20-7.13 (m, 4H), 7.07-6.95 (m, 6H), $4.80(\mathrm{~d}, \mathrm{~J}=3.4 \mathrm{~Hz}, 1 \mathrm{H}), 3.81(\mathrm{td}, \mathrm{J}=10.9,4.1 \mathrm{~Hz}, 1 \mathrm{H}), 3.47(\mathrm{dd}, \mathrm{J}=11.0,3.4$ $\mathrm{Hz}, 1 \mathrm{H}), 3.15(\mathrm{dd}, \mathrm{J}=15.1,4.1 \mathrm{~Hz}, 1 \mathrm{H}), 2.88(\mathrm{dd}, \mathrm{J}=15.1,10.8 \mathrm{~Hz}, 1 \mathrm{H}) \cdot{ }^{13} \mathrm{C}\left\{{ }^{1} \mathrm{H}\right\} \mathrm{NMR}\left(125 \mathrm{MHz}\right.$, acetone- $\left.\mathrm{d}_{6}\right): \delta$ 175.0, 173.4, 143.5, 139.9, 130.7, 129.5, 128.5, 128.2, 127.1, 126.8, 71.3, 53.8, 45.0, 39.0. IR (atr): 3400-2500 (-OH/-COOH, broad), $1730(-\mathrm{ROOH}, \mathrm{s}), 1681(\mathrm{C}=\mathrm{O}, \mathrm{s}), 1493\left(-\mathrm{CH}_{2}-, \mathrm{m}\right), 1416(\mathrm{w}), 1160$ (s) (-COOH), $1204(\mathrm{~m})$, 1087 (s) R-(HCOH)-R, m), 695 (5 adjacent H (Ph), s). UV-vis (acetone): $208 \mathrm{~nm}$ (max), $211 \mathrm{~nm}$ (max), $214 \mathrm{~nm}$ (max), and $216 \mathrm{~nm}$ (shoulder).

2-Hydroxy-3-(1H-indol-3-yl)-4-phenylhexanedioic Acid (Enantiomeric Pair of RRR and SSS) $\left(\mathbf{2} \mathbf{H}_{\mathbf{2}}\right)$. The product was synthesized according to the general procedure for protonated diacids from product 2. ${ }^{1} \mathrm{H} \mathrm{NMR}(500 \mathrm{MHz}$, acetone- $\left.\mathrm{d}_{6}\right)$ : $\delta 10.65$ (broad, $\left.1 \mathrm{H}\right), 9.91(\mathrm{~s}, 1 \mathrm{H}), 7.60(\mathrm{~d}, 1 \mathrm{H}), 7.32-7.28(\mathrm{~m}, 3 \mathrm{H}), 7.22(\mathrm{~d}, 1 \mathrm{H}), 7.10-7.06(\mathrm{~m}, 2 \mathrm{H})$, 6.99-6.94 (m, 2H), 6.92-6.88 (m, $1 \mathrm{H}), 4.71(\mathrm{~d}, \mathrm{~J}=2.8 \mathrm{~Hz}, 1 \mathrm{H}), 3.95(\mathrm{dd}, \mathrm{J}=9.4,2.8 \mathrm{~Hz}, 1 \mathrm{H}), 3.87(\mathrm{dt}, \mathrm{J}=10.0,4.3$ $\mathrm{Hz}, 1 \mathrm{H}), 3.11-2.99(\mathrm{~m}, 2 \mathrm{H}) .{ }^{13} \mathrm{C}\left\{{ }^{1} \mathrm{H}\right\}$ NMR $\left(125 \mathrm{MHz}\right.$, acetone- $\left.\mathrm{d}_{6}\right): \delta 175.5,173.7,144.2,136.9,129.3,128.9,128.5$, 126.8, 125.0, 121.6, 119.9, 119.2, 113.0, 111.8, 71.3, 45.9, 45.3, 38.4. IR (atr): 3391 (N- H, s), 1722 (-ROOH, s), 1455, $1425\left(-\mathrm{CH}_{2}-, \mathrm{m}\right), 1275,1214(-\mathrm{COOH}, \mathrm{m}), 1106$ (R-HCOH-R, s), 739, 697 (5 adjacent H (Ph), s). UV-vis (acetone): $207 \mathrm{~nm}$ (max), $212 \mathrm{~nm}$ (max), $215 \mathrm{~nm}$ (max), and $220 \mathrm{~nm}$ (shoulder).

2-Hydroxy-3-phenyl-4-(4-methylphenyl)hexanedioic Acid (Enantiomeric Pair of RRR and SSS) (4) $\mathbf{H}_{\mathbf{2}}$ ). The product was synthesized according to the general procedure for protonated diacids from product 4. ${ }^{1} \mathrm{H} \mathrm{NMR}(500 \mathrm{MHz}$, acetone- $\left.\mathrm{d}_{6}\right): \delta$ 7.22-7.18 (m, 2H), 7.06-6.99 (m, 5H), 6.90-6.85 (m, 2H), $4.79(\mathrm{~d}, \mathrm{~J}=3.4 \mathrm{~Hz}, 1 \mathrm{H}), 3.79(\mathrm{dt}, \mathrm{J}=10.9$, $4.1 \mathrm{~Hz}, 1 \mathrm{H}), 3.47(\mathrm{dd}, \mathrm{J}=11.0,3.4 \mathrm{~Hz}, 1 \mathrm{H}), 3.12(\mathrm{dd}, \mathrm{J}=15.0,4.1 \mathrm{~Hz}, 1 \mathrm{H}), 2.85(\mathrm{dd}, \mathrm{J}=15.0,10.8 \mathrm{~Hz}, 1 \mathrm{H}), 2.14(\mathrm{~s}$, 
3H). ${ }^{13} \mathrm{C}\left\{{ }^{1} \mathrm{H}\right\}$ NMR $\left(125 \mathrm{MHz}\right.$, acetone- $\left.\mathrm{d}_{6}\right): \delta 175.0,173.4,140.5,139.9,135.9,130.7,129.4,129.2,128.2,127.1$, 71.3, 53.8, 44.5, 39.2, 20.9. IR (atr): 1729 (-ROOH, s), 1671 (C回O, s), $1493\left(-\mathrm{CH}_{2-}, \mathrm{m}\right), 1453\left(-\mathrm{CH}_{3}, \mathrm{w}\right), 1216(\mathrm{~m})$, 1158 (w), 1086 (s) (R-HCOH- R), 837, 805 (2 adjacent H (Ph), m) 741, 695 (5 adjacent H (Ph), s). UV-vis (acetone): $208 \mathrm{~nm}(\max ), 212 \mathrm{~nm}(\max ), 214 \mathrm{~nm}(\max ), 217 \mathrm{~nm}(\max )$, and $222 \mathrm{~nm}$ (shoulder).

2-Hydroxy-3-phenyl-4-(4-fluorophenyl)hexanedioic Acid (Enantiomeric Pair of RRR and SSS) $\left(\mathbf{7 H}_{2}\right)$. The product was synthesized according to the general procedure for protonated diacids from product 7. ${ }^{1} \mathrm{H} \mathrm{NMR}(500 \mathrm{MHz}$, acetone- $\left.\mathrm{d}_{6}\right): \delta 7.20-7.15(\mathrm{~m}, 4 \mathrm{H}), 7.06-6.98(\mathrm{~m}, 3 \mathrm{H}), 6.84-6.79(\mathrm{~m}, 2 \mathrm{H}), 4.81(\mathrm{~d}, \mathrm{~J}=3.4 \mathrm{~Hz}, 1 \mathrm{H}), 3.83(\mathrm{td}, \mathrm{J}=11.0$, $4.1 \mathrm{~Hz}, 1 \mathrm{H}), 3.45(\mathrm{dd}, \mathrm{J}=11.1,3.4 \mathrm{~Hz}, 1 \mathrm{H}), 3.17(\mathrm{dd}, \mathrm{J}=15.2,4.1 \mathrm{~Hz}, 1 \mathrm{H}), 2.86(\mathrm{dd}, \mathrm{J}=15.1,11.0 \mathrm{~Hz}, 1 \mathrm{H}) .{ }^{13} \mathrm{C}\left\{{ }^{1} \mathrm{H}\right\}$ $\operatorname{NMR}\left(125 \mathrm{MHz}\right.$, acetone- $\left.\mathrm{d}_{6}\right): \delta$ 174.9, 173.3, 162.9, 161.0, 139.7, 139.6, 139.6, 131.3, 131.2, 130.7, 128.2, 127.2, 115.1, 115.0, 71.1, 53.8, 44.3, 39.1. ${ }^{19} \mathrm{~F}$ NMR (470 MHz, acetone-d 6 ): $\delta-118.7$. IR (atr): $3437(-\mathrm{OH}, \mathrm{br})$, 3200-2800 (-COOH, br), $1730(\mathrm{~m}), 1680(\mathrm{~m}), 1158(\mathrm{~s})(-\mathrm{COOH}), 1218(\mathrm{~s}), 1090(\mathrm{~s})(\mathrm{R}-\mathrm{HCOH}-\mathrm{R}), 847(\mathrm{~s}), 811(\mathrm{~m})$, $699(\mathrm{~s}), 671(\mathrm{w}), 568(\mathrm{~s}), 420(\mathrm{~m})$ (R-Ph-F, either 2H adjacent vibrations or C-F movements), $746(\mathrm{~s}), 718(\mathrm{w}), 628$ (m) (Ph-R, 5H adjacent). UV-vis (acetone): $209 \mathrm{~nm}$ (max) and $214 \mathrm{~nm}$ (shoulder).

2-Hydroxy-5-methyl-3,4-diphenylhexanedioic Acid (Enantiomeric Pair of RRRR and SSSS) $\left(\mathbf{1 0 H}_{\mathbf{2}}\right)$. The product was synthesized according to the general procedure for protonated diacids from product $10 .{ }^{1} \mathrm{H} \mathrm{NMR}(500 \mathrm{MHz}$, acetone- $\left.\mathrm{d}_{6}\right): \delta 7.24-7.20(\mathrm{~m}, 2 \mathrm{H}), 7.14-7.10(\mathrm{~m}, 2 \mathrm{H}), 7.07-6.95(\mathrm{~m}, 6 \mathrm{H}), 4.77(\mathrm{~d}, \mathrm{~J}=3.4 \mathrm{~Hz}, 1 \mathrm{H}), 4.15(\mathrm{dd}, \mathrm{J}=11.3$, $4.7 \mathrm{~Hz}, 1 \mathrm{H}), 3.75(\mathrm{dd}, \mathrm{J}=11.3,3.4 \mathrm{~Hz}, 1 \mathrm{H}), 3.31(\mathrm{dq}, \mathrm{J}=7.0,4.7 \mathrm{~Hz}, 1 \mathrm{H}), 1.17(\mathrm{~d}, \mathrm{~J}=7.0 \mathrm{~Hz}, 3 \mathrm{H}) .{ }^{13} \mathrm{C}\left\{{ }^{1} \mathrm{H}\right\} \operatorname{NMR}(125$ $\mathrm{MHz}$, acetone- $\left.\mathrm{d}_{6}\right): \delta 176.1,175.0,139.8,139.2,131.0,130.9,128.2,128.1,127.1,126.9,71.2,50.0,48.2,41.5$, 11.3. IR (atr): 1704 (-ROOH, s), 1453, $1392\left(-\mathrm{CH}_{3}, \mathrm{~m}\right), 1233$ (-COOH, s), 1093 (R- HCOH-R, s), 697 (5 adjacent H (Ph), s). UV-vis (acetone): $209 \mathrm{~nm}$ (max), $214 \mathrm{~nm}$ (shoulder), and $216 \mathrm{~nm}$ (shoulder).

\section{Associated content}

\section{Supporting Information}

The Supporting Information is available free of charge at https://pubs.acs.org/doi/10.1021/acs.joc.9b03320.

X-ray crystallographic data for compounds 1 and 2 (CCDC 1948055 (1) and 1948056 (2))

Work safety; optimization of methods 1 and 2; product yields; spectroscopic and crystal structure data; mechanistic studies.

\section{Notes}

The authors declare no competing financial interest. 


\section{Acknowledgements}

A.E. acknowledges the University of Helsinki and Magnus Ehrnrooth Foundation for financial support.

\section{REFERENCES}

(1) van Haveren, J.; Scott, E. L.; Sanders, J. Bulk chemicals from biomass. Biofuels Bioprod., Bioref. 2008, 2, 41-57.

(2) Sheldon, R.A. Green and sustainable manufacture of chemicals from biomass: state of the art. Green Chem. 2014, 16, 950-963.

(3) Li, S.-Y.; Ng, I-S.; Chen, P. T.; Chiang, C.-J.; Chao, Y.-P. Biorefining of protein waste for production of sustainable fuels and chemicals. Biotechnol. Biofuel 2018, 11, 256-271.

(4) Tuck, C. O.; Pérez, E.; Horvàth, I. T.; Sheldon, R. A.; Poliakoff, M. Valorization of Biomass: Deriving More Value from Waste. Science 2012, 337, 695-699.

(5) Lynd, L. R. The grand challenge of cellulosic biofuels. Nat. Biotechnol. 2017, 35, 912-915.

(6) Ohkuma, H.; Naruse, N.; Nishiyama, Y.; Tsuno, T.; Hoshino, Y.; Sawada, Y.; Konishi, M.; Oki, T. Sultriecin, a new antifungal and antitumor antibiotic from Streptomyces roseiscleroticus: production, isolation, structure and biological activity. Antibiot. 1992, 45, 1239-1249.

(7) Konno, H.; Hiroya, K.; Ogasawara, K. A New Tactic for Diastereo- and Enantiocontrolled Synthesis of (-)-Malyngolide via Catalytic Meso-Asymmetrization. Tetrahedron lett. 1997, 38, 6023-6026.

(8) Cardona, W.; Quiñones, W.; Robledo, S.; Vélez, I. D.; Murga, J.; García-Fortanet, J.; Carda, M.; Cardona, D.; Echeverri, F. Antiparasite and antimycobacterial activity of passifloricin analogues. Tetrahedron 2006, 62, 4086-4092.

(9) McMurry, J. E.; Dushin, R.G. Total Synthesis of ( \pm )-Isolobophytolide and ( \pm )-Crassin by Titanium-Induced Carbonyl Coupling. J. Am. Chem. Soc. 1990, 112, 6942-6942.

(10) Zhang, H.; Conte, M. M.; Capon, R. J. Franklinolides A-C from an Australian Marine Sponge Complex: Phosphodiesters Strongly Enhance Polyketide Cytotoxicity. Angew. Chem. Int. Ed. 2010, 49, 9904-9906.

(11) Igarashi, Y.; Asano, D.; Furihata, K.; Oku, N.; Miyanaga, S.; Sakurai, H.; Saiki, I. Absolute configuration of pterocidin, a potent inhibitor of tumor cell invasion from a marine-derived Streptomyces. Tetrahedron lett. 2012, 53, 654-656.

(12) Dufossé, L.; Latrasse, A.; Spinnler, H.-E. Importance des lactones dans les arômes alimentaires : structure, distribution, propriétés sensorielles et biosynthèse. Sciences des Aliments 1994, 14, 17-50.

(13) CCDC 1948055 (1) and 1948056 (2) contain the supplementary crystallographic data for this paper. These data can be obtained free of charge from the Cambridge Crystallographic Data Centre. For details see SI.

(14) Willems, J. G. H.; de Vries, J. G.; Nolte, R. J. M.; Zwanenburg, B. Asymmetric Imine Isomerisation in the Enantioselective Synthesis of Chiral Amines from Prochiral Ketones. Tetrahedron Lett. 1995, 36, 3917-3920.

(15) Yasumoto, M.; Ueki, H.; Soloshonok, V. A. Thermal 1,3-proton shift reaction and its application for operationally convenient and improved synthesis of $\alpha$-(trifluoromethyl)benzylamine. J. Fluor. Chem. 2007, 128, 736-739.

(16) Chen, F.-F.; Zhang, Y.-H.; Zhang, Z.-J.; Liu, L.; Wu, J.-P.; Xu, J.-H.; Zheng, G.-W. An Ammonium-Formate-Driven Trienzymatic Cascade for $\omega$-Transaminase-Catalyzed (R)-Selective Amination. J. Org. Chem. 2019, 84, 14987-14993.

(17) Aramendía, M. A.; Borau, V.; Jiménez, C.; Marinas, J. M.; Ruiz, J. R.; Urbano, F. J. Activity of Baisc Catalysts in the Meerwein-Ponndorf-Verley reaction of Benzaldehyde with Ethanol. J. Colloid Interface Sci. 2001, 238, 385-389.

(18) Wang, F.; Ta, N.; Shen, W. MgO nanosheets, nanodisks, and nanofibers for the Meerwein-Ponndorf-Verley reaction. Appl. catal. A-Gen. 2014, 475, 76-81.

(19) Shannon, R. D. Revised Effective Ionic Radii and Systematic Studies of Interatomic Distances in Halides and Chalcogenides. Acta Cryst. 1976, A32, 751-767.

(20) Xiao, M.; Yue, X.; Xu, R.; Tang, W.; Xue, D.; Li, C.; Lei, M. Xiao, J.; Wang, C. Transition-Metal-Free Hydrogen Autotransfer: Diastereoselective N-Alkylation of Amines with Racemic Alcohols. Angew. Chem. Int. Ed. 2019, 58, 10528-10536.

(21) Collins, I. Saturated and unsaturated lactones. J. Chem. Soc. Perkin Trans. 1998, 1, 1869-1888.

(22) Palanichamy, K.; Kaliappan, K. Synthesis of Saturated Oxygenated Heterocycles I, Topics in Heterocyclic Chemistry; Cossy, J., Ed.; Springler-Verlag: Berlin, 2014; vol. 35, 97-140.

(23) Marco, J. A.; Carda, M. Natural Lactones and Lactams: Synthesis, Occurrence and Biological Activity; Janecki, T.; Ed.; Wiley-VCH: Weinheim, 2013; 51-100. 